SJ Quinney College of Law, University of Utah Utah Law Digital Commons

Wallace Stegner Center for Land, Resources, and the Environment publications

2019

Measuring the NEPA Litigation Burden: A Review of 1,499 Federal Court Cases

John C. Ruple

Kayla Race

Follow this and additional works at: https://dc.law.utah.edu/stegner_pubs

Part of the Environmental Law Commons, and the Natural Resources Law Commons 


\title{
MEASURING THE NEPA LITIGATION BURDEN: A REVIEW OF 1,499 FEDERAL COURT CASES
}

BY

\author{
JOHN C. RUPLE* \& KAYLA M. RACE**
}

We reviewed thirteen years of National Environmental Policy Act (NEPA) litigation data reported by the White House Council on Environmental Quality, summarizing 1,499 federal court opinions to assess: 1) how frequently NEPA compliance efforts result in litigation; 2) how agency NEPA decisions fare in court; and 3) how NEPA litigation outcomes compare to outcomes in other challenges to federal agency decisions. We found that only one in 450 NEPA decisions were litigated and that the rate of NEPA challenges declined during the thirteen-year study period. We noted an inverse relationship between the amount of time spent on Environmental Impact Statement (EIS) preparation and the likelihood that an EIS would be challenged in court. We also found that while federal agencies prevail in NEPA litigation at slightly higher rates than in other civil cases where the government is a defendant, environmental plaintiffs win at higher rates than any other class of NEPA challengers. Overall, we conclude that the NEPA litigation burden may be overstated because few decisions are challenged in court, the rate of challenges is declining, and environmental plaintiffs are likely to bring only cases where they have a high likelihood of success. We therefore recommend against imposing strict deadlines and page limits on EISs, as these "reforms" may do little to reduce the NEPA compliance burden while limiting opportunities for public engagement. Indeed, aggressive streamlining may make it more difficult to satisfy NEPA's hard-look requirement and therefore result in increased litigation.

\footnotetext{
*John C. Ruple is a Professor of Law (Research) and Wallace Stegner Center Fellow at the University of Utah's S.J. Quinney College of Law.

${ }^{* *}$ Kayla M. Race is a graduate of the S.J. Quinney College of Law, University of Utah. Thank you to David Adelman and Heather Tanana for their careful review and thoughtful comments on early drafts of this paper, and to the Wilburforce Foundation for supporting this research effort. Project funders were not involved in development of study methodology, nor did they review any aspect of this Article prior to publication or otherwise exercise editorial control. The views expressed herein do not necessarily represent those of the state of Utah, the University of Utah, project funders, or our reviewers.
} 


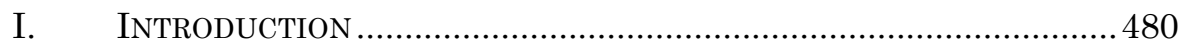

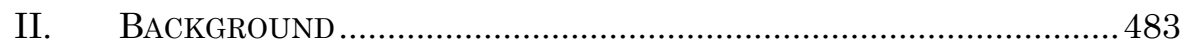

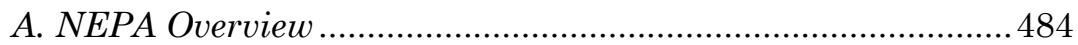

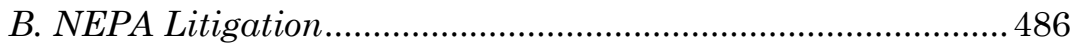

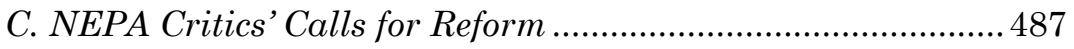

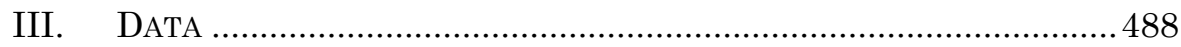

A. CEQ NEPA Production and Litigation Data ........................489

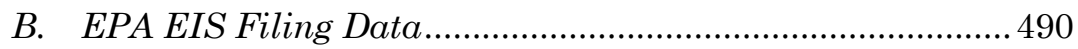

C. U.S. Attorneys' Office Federal Environmental

Litigation Data

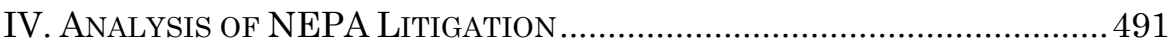

A. How Burdensome is NEPA Compliance?...............................492

1. Number and Types of NEPA Documents

Governmentwide

2. EIS Production Trends over Time and By Agency

3. The Timing of NEPA Compliance .....................................496

4. EIS Production Time Compared to Litigation Rates

B. How Burdensome is NEPA Litigation?.

1. NEPA Lawsuit Filing Trends Governmentwide 500

2. NEPA Lawsuit Filings Compared to All Civil Suits Against the U.S. 502

3. Portion of NEPA Decisions Challenged in Court. 503

4. Type of NEPA Documents Challenged 504

5. Portion of Final EISs and Supplemental Final EISs Resulting in Court Rulings... 505

6. NEPA Litigation Burden by Agency ...............................506

C. NEPA Litigation Outcomes .........................................................

1. NEPA Litigation "Win" Rates.

2. Success Rates Based on Type of NEPA

Review.

3. NEPA Outcomes by Lead Agency 515

4. NEPA Litigation Outcomes Compared to Other Federal Cases

V. CONCLUSION AND RECOMMENDATIONS. 521

\section{INTRODUCTION}

This Article reviews thirteen years of data reported by the White House Council on Environmental Quality (CEQ) on federal court 
litigation involving National Environmental Policy Act ${ }^{1}$ (NEPA) compliance to determine how often NEPA documents are challenged in court and how NEPA documents fare in litigation. Little data exists on the number of NEPA analyses conducted annually, or on litigation arising from those decisions. Our analysis narrows this gap in the literature, and in so doing, illuminates ongoing efforts to improve NEPA efficacy and to update NEPA's implementing regulations. ${ }^{2}$ We found that NEPA litigation does not appear to be unreasonably burdensome, and that the rate at which NEPA decisions are challenged has declined steadily over time.

NEPA has been described as the Magna Carta of environmental laws. ${ }^{3}$ NEPA declares that it is national policy to "encourage productive and enjoyable harmony between man and his [or her] environment; [and] to promote efforts which will prevent or eliminate damage to the environment and biosphere and stimulate the health and welfare of man...." NEPA's lofty goals are met through requirements that federal agencies identify and analyze impacts on the environment prior to taking, authorizing, or funding "major Federal actions significantly affecting the quality of the human environment." 5 NEPA however, "does not mandate particular results," nor does it require agencies to mitigate environmental impacts or choose the least environmentally damaging alternative. ${ }^{6}$ Instead, NEPA requires that agencies take a "hard look" at the environmental impacts of their actions and consider a range of alternative means of achieving agency goals before undertaking federal actions. ${ }^{7}$ Completing this hard look can involve significant time ${ }^{8}$ and expense..$^{9}$

Whether NEPA's environmental benefits justify such environmental reviews is hotly contested, and some contend that NEPA litigation has been used by environmentalists as a tool to delay much

1 National Environmental Policy Act of 1969, 42 U.S.C. $§ \S 4321-4370$ h (2012).

2 On June 20, 2018, the White House Council on Environmental Quality (CEQ) published an advanced notice of proposed rulemaking for revisions to NEPA's implementing regulations. Update to the Regulations for Implementing the Procedural Provisions of the National Environmental Policy Act, 83 Fed. Reg. 28591 (June 20, 2018).

3 DANiEl R. MANDELKER, NEPA LAW AND Litigation $§ 1: 1$ (2019).

442 U.S.C. $\S 4321$.

5 Id. $\S 4332(2)(\mathrm{C})$.

6 Robertson v. Methow Valley Citizens Council, 490 U.S. 332, 350 (1989).

7 Id. (quoting Kleppe v. Sierra Club, 427 U.S. 390, 410 n.21 (1976)).

8 The CEQ reports that, across all federal agencies, completion time for an Environmental Impact Statement (EIS) - from issuance of a notice of intent to prepare an EIS through publication of a record of decision - took an average (mean) of 4.5 years and a median of 3.6 years. One quarter of EISs took less than 2.2 years to complete, and one quarter took more than 6.0 years to complete. ExEC. OfFICE OF THE PRESIDENT, COUNCIL ON EnVTl. Quality, EnVironmental ImPaCt Statement Timelines (2010-2017) 1 (2018), https://perma.cc/VLM8-3E4F [hereinafter CEQ EIS TIMELINES].

9 See U.S. Gov't ACCOUNTABILITY OfFICE, GAO-14-370, NATIONAL ENVIRONMENTAL POLICY ACT: LiTTLE INFORMATION EXISTS ON NEPA ANALYSES 13-14 (Apr. 2014) (citing estimates that "an EIS typically cost[s] from $\$ 250,000$ to $\$ 2$ million"). 
needed projects. According to the Heritage Foundation, "[a]ctivists for years have used judicial review to challenge (and delay) development." 10 Staff to the U.S. House of Representatives Committee on Natural Resources asserted that NEPA is the "weapon of choice"-a form of "lawfare," used by activists for the "manipulation of the legal system" to "stop, delay, restrict, or impose additional costs on all types of federal action."11 Critics' concerns often focus on NEPA or NEPA litigation allegedly adding cost or time to federal infrastructure projects. ${ }^{12}$

While soundbites such as these paint a vivid picture, they are based on anecdotal information rather than a systematic review of NEPA litigation, and they fail to consider the reasons for project delays, many of which have nothing to do with NEPA. ${ }^{13}$ While we agree that efficiencies can be gained with respect to NEPA, we also believe that changes to our foundational environmental laws should be based on rigorous and comprehensive analysis.

This Article attempts to elevate the discussion surrounding NEPA by empirically evaluating whether NEPA litigation poses an unreasonable burden on the federal agencies charged with implementing NEPA, or on the federal courts that must resolve NEPA challenges. This Article assesses: 1) how frequently NEPA compliance efforts result in litigation; 2) how NEPA lawsuits are resolved; and 3)

10 Diane Katz, Time to Repeal the Obsolete National Environmental Policy Act (NEPA), BACKGROUNDER, Mar. 14, 2018, at 6, https://perma.cc/9X6V-B5YL.

11 Majority StAFF OF H. Subcomm. ON OVERSight \& InVESTigations, 115TH CONG., HEARING Memorandum on The Weaponization of the National EnVIRONMENTAL POLICY ACT AND THE IMPLICATIONS OF ENVIRONMENTAL LAWFARE 1-2 (2018); see also MAJORity StAFF OF H. SUbCOMM. ON Oversight \& InVESTigations, 115Th Cong., HEARING MEM. ON MODERNIZING NEPA FOR THE 21ST CENTURY 4 (2017) (NEPA "has become a magnet for litigation, with hundreds of NEPA-related lawsuits against the federal government filed or open each year").

12 See Hearing Memorandum on The Weaponization of the national ENVIRONMENTAL POLICY ACT AND THE IMPLICATIONS OF ENVIRONMENTAL LAWFARE, supra note 11, at 5-6. Agencies that tend to handle major infrastructure projects such as Federal Highway Administration and the Federal Aviation Administration take longer than average to complete their EISs. See CEQ EIS TIMELINES, supra note 8, at 10; see also discussion infra Part IV.B.6. These agencies are also sued less often than their sister agencies. See David E. Adelman \& Robert L. Glicksman, Presidential and Judicial Politics in Environmental Litigation, 50 ARIZ. ST. L.J. 3, 30 (2018) (noting that the Federal Highway Administration faced only $30 \%$ of the EIS lawsuits that would be expected based on its share of EISs produced, while the Department of Defense faced only $70 \%$ of the EIS lawsuits expected, and the U.S. Army Corps of Engineers faced only 50\% of the EIS lawsuits expected).

13 See generally, e.g., William Perry Pendley, Mountain States Legal Found., NEPA Needs U.S. Supreme Court Intervention, CARE ENERGY CounCIL (June 23, 2009), https://perma.cc/GP2B-TCFV; The Weaponization of the National Environmental Policy Act and the Implications of Environmental Lawfare: Hearing Before the H. Comm. on Nat. Res., 115th Cong. 1, 5-6 (2018) (statement of Melissa L. Hamsher, Vice President, Environmental, Health, Safety, and Regulatory, Eclipse Resources Corporation). But cf., LINDA Luther, Cong. Research Serv., RL33267, The National Environmental Policy ACT: STREAMLINING NEPA, at CRS-3 (updated 2007) (explaining that delays may be unrelated to NEPA compliance). 
how NEPA litigation outcomes compare to outcomes in other environmental litigation involving the federal government.

After reviewing thirteen years of NEPA litigation and summary data for 1,499 court opinions (published and unpublished) reported by the CEQ, ${ }^{14}$ we conclude that NEPA litigation has not been used excessively in order to stop or delay federal decisions. Only a small fraction of NEPA decisions result in litigation-approximately one in 450 decisions are litigated. ${ }^{15}$ Further, the amount of NEPA litigation declined during the thirteen year study period.16 Environmental plaintiffs, however, prevail in NEPA claims at a higher rate than other plaintiffs, ${ }^{17}$ and their rate of success when combined with selective litigation fillings suggests that these groups are reluctant to expend limited resources on weak legal cases. We also found that agencies that spend less time on their NEPA analysis are sued at a higher rate than their more contemplative counterparts. ${ }^{18}$

Part II of this Article provides background on NEPA, NEPA litigation, and calls for NEPA reform. Part III describes the main sources of data used in this analysis: CEQ's NEPA production and litigation data, the Environmental Protection Agency's (EPA's) EIS filing data, and data on federal environmental litigation obtained from the U.S. Attorneys' Office. Part IV analyzes that data to assess the extent of the burden imposed by NEPA compliance, the extent of the burden imposed by NEPA litigation, and how federal agencies fare in NEPA litigation. Part V concludes and identifies several NEPA reform recommendations.

\section{BACKGROUND}

NEPA is a foundational element of our national effort to protect human health and the environment. But where other statutes protect specific environmental amenities, NEPA guards the process under which federal agencies make decisions affecting the environment, guaranteeing the public an opportunity to offer input before those decisions are made. ${ }^{19}$ This review is intended to be proportional to the

14 See White House Council on Envtl. QuALiTy, NEPA Litigation SuRVeYs: 20012013, https://perma.cc/J7A4-GTM7 (last visited Apr. 18, 2020) [hereinafter NEPA LITIGATION REPORT].

15 See discussion infra Part IV.B.3.

16 See discussion infra Part IV.B.3.

17 Adelman \& Glicksman, supra note 12, at 27 (noting that environmental plaintiffs win $35 \%$ of NEPA cases at the district court and $27 \%$ on appeal, while other plaintiffs win just $16 \%$ of NEPA cases at the district court and only $14 \%$ on appeal).

18 See infra note 124 and accompanying text.

19 See Methow Valley Citizens Council, 490 U.S. 332, 349-54 (1989) (explaining that "NEPA itself does not mandate particular results, but simply prescribes the necessary process," and that the NEPA process ensure that agencies "will carefully consider[ ] detailed information concerning significant environmental impacts; it also guarantees that 
risk of environmental harm, with the most significant decisions undergoing the most rigorous review. The idea is simple, but the practice can be difficult to implement. Before evaluating the burden imposed by NEPA litigation, this Part provides an overview of the Act itself, the litigation that NEPA compliance has spawned, and pending calls for NEPA reform.

\section{A. NEPA Overview}

Under NEPA, "major federal actions significantly affecting the quality of the human environment" must undergo an environmental review before those actions can proceed. ${ }^{20}$ When a federal project's impacts are known to be significant in terms of their context and intensity, compliance requires completion of an Environmental Impact Statement (EIS). ${ }^{21}$ EISs are prepared in stages. At the outset of the NEPA process, the lead agency publishes a Notice of Intent to Prepare an EIS (NOI) in the Federal Register. ${ }^{22}$ The NOI describes the action contemplated, as well as the reasons for the action, and invites public comments on environmental issues raised by the proposed action. ${ }^{23}$ After receiving and considering public comment, the lead agency prepares a Draft EIS analyzing the direct, indirect, and cumulative impacts of both the proposed action and one or more alternative means of achieving the desired outcome. ${ }^{24}$ The Draft EIS compares the impacts that are likely to result from each alternative to the impacts that would result from a continuation of the status quo (the "no action alternative"). ${ }^{25}$ The public is then invited to review the Draft EIS and provide comments, which the agency reviews and considers, responding as appropriate and revising the EIS where needed before issuing a Final EIS and Record of Decision (ROD). ${ }^{26}$ If significant deficiencies are identified in a Draft or Final EIS, the lead agency may prepare a Revised or Supplemental EIS. ${ }^{27}$

Most federal actions do not involve significant environmental impacts and therefore do not require an EIS. NEPA authorizes agencies to promulgate regulations specifying "Categorical Exclusions" (CEs) categories of actions that the agency determines do not individually or cumulatively have a significant impact on the human environment. ${ }^{28}$

the relevant information will be made available to the larger audience that may also play a role in both the decision-making process and the implementation of that decision").

2042 U.S.C. $\S 4332(2)$ (C) (2012).

2140 C.F.R. $\S 1502.4$ (2018).

22 Id. $\S \S 1501.7,1508.22$.

23 Id. $\S 1506.6$

24 Id. $§ 1502.14-16$.

25 Id. $\$ 1502.14(\mathrm{~d})$.

26 Id. $\S 1503.1, .4$.

27 Id. § 1502.9(a), (c). EIS naming conventions vary, and for this Article's analysis we treat all but the first iteration of an EIS as a Supplemental EIS.

28 Id. $\S 1508.4,1507.3(\mathrm{~b})(1)-(2)(\mathrm{ii})$. 
Actions that fall within one of these regulatory CEs can be approved without an EIS, provided that the action does not involve "extraordinary circumstances." 29 Congress has also created statutory CEs for certain types of oil and natural gas development. 30

Actions that fall outside the scope of a $\mathrm{CE}$ can avoid preparation of an EIS if a federal agency prepares an Environmental Assessment (EA) and determines that the proposed action would not cause significant impacts. ${ }^{31}$ If projected impacts are not significant, the agency issues a Finding of No Significant Impact (FONSI), the NEPA review process is complete, and an EIS is not required. ${ }^{32}$ Alternatively, the agency may issue a "mitigated FONSI," which includes measures to reduce the impact of the proposed project to a level that is not significant. ${ }^{33}$ If the proposed action is determined to have a significant effect, then however, an EIS is required. ${ }^{34}$ Most federal actions do not require completion of an EIS because they are authorized in a CE or are determined in an EA not to have significant environmental impacts. ${ }^{35}$

While the EPA tracks the number of EISs prepared annually, ${ }^{36}$ there are no centralized figures on the number of EAs or CEs completed each year, and estimates of such numbers vary wildly. The U.S. Government Accountability Office (GAO) estimates that 95\% of NEPA documents are CEs, nearly $5 \%$ are EAs, and less than $1 \%$ are EISs. ${ }^{37}$ Data compiled by the EPA shows that an average of 513 EISs are published each year governmentwide. ${ }^{38}$ Based on GAO and EPA data, we can estimate that the federal government issues approximately

\footnotetext{
29 Id. $\S 1508.4$.

3042 U.S.C. $\S 15942$ (a) (2012).

3140 C.F.R. $\S 1508.9$.

32 Id. $\S 1508.13$.

33 Id. $\S 1501.4$; Final Guidance for Federal Departments and Agencies on the Appropriate Use of Mitigation and Monitoring and Clarifying the Appropriate Use of Mitigated Findings of No Significant Impact, 76 Fed. Reg. 3843, 3847 (Jan. 21, 2011).

3440 C.F.R. $\S 1501.4$.

35 See U.S. Gov'T ACCOUNTABILITy OfFICE, supra note 9, at 8 (explaining that less than $1 \%$ of federal actions require an EIS).

36 Environmental Impact Statement (EIS) Database, U.S. EnVTl. ProteCtion AGenCY, https://perma.cc/6W5S-B3WR (last updated Feb. 4, 2020) [hereinafter EPA EIS Database].

37 U.S. GOv'T ACCOUNTABILITY OFFICE, supra note 9, at 8. However, these are rough estimates that vary considerably by agency. For example, the GAO noted that the Department of Energy reported $95 \%$ of its NEPA documents are CEs, but $2.6 \%$ were EAs and $2.4 \%$ were EISs, while the Forest Service reported that only $78 \%$ of its NEPA analyses were CEs, $20 \%$ were EAs, and $2 \%$ were EISs. Id. We reviewed NEPA decisions by the Bureau of Land Management and found that $63.1 \%$ of their NEPA reviews were documented in a CE, $36.5 \%$ in an EA, and just $0.4 \%$ in an EIS. See infra Part IV.A.1.

38 Calculated from data available at EPA EIS Database, supra note 36 . This calculated average is for the span of years from 2001 through 2013 and reflects both Draft and Final EISs. We contacted the GAO and confirmed that the number of EISs reported in their report, U.S. GOV'T ACCOUNTABILITY OfFICE, supra note 9, reflects the total number of Draft and Final EISs completed, rather than only Final EISs.
} 
48,700 CEs and roughly 2,560 EAs annually, for a total of roughly 51,300 NEPA analyses each year. ${ }^{39}$

\section{B. NEPA Litigation}

CEs, FONSIs, and RODs are all final agency actions and subject to federal court review under the Administrative Procedure Act. ${ }^{40}$ When reviewing a NEPA decision, courts consider compliance with NEPA's procedural requirements and whether the agency took the requisite "hard look" at likely impacts. ${ }^{41}$

There is currently no governmentwide system tracking NEPA litigation or its associated timing and costs. NEPA litigation data was collected and published by the CEQ from 2001 through 2013.42 With limited data to draw from, few scholarly efforts have assessed NEPA litigation's impact on government agencies. The scholarship that does exist tends to be limited in the scope of agencies reviewed, the timeframe covered, or to other narrow questions. For example, multiple studies focus on NEPA litigation at the U.S. Forest Service. ${ }^{43}$ The Forest Service may receive more attention because it manages 192.9 million acres of land (roughly $26 \%$ of all federal land and over $8 \%$ of the entire United States) across forty-three states and Puerto Rico. ${ }^{44}$ The Forest Service is also called upon to balance a host of competing uses, from logging to endangered species protection. ${ }^{45}$ These tradeoffs invariably leave some stakeholders dissatisfied, and those groups or individuals can turn to the courts for redress. Indeed, during our thirteen-year study period, Forest Service NEPA decisions were challenged at over twice the rate of any other federal agency, and cases involving the Forest Service make up over one-third of all NEPA litigation. 46

39 This calculation is based on an extrapolation from the GAO's reported percentages for each kind of NEPA analysis and the number of EISs tracked and reported by the EPA, U.S. GOV'T ACCOUNTABILITY OFFICE, supra note 9. Other scholars recently estimated that the federal government annually produced 137,750 CEs, 6,820 EAs, and 435 (draft and final) EISs for the period of 2008-2015. Adelman \& Glicksman, supra note 12, at 16-17.

405 U.S.C. $\S \S 701-706$ (2012); Lujan v. Nat'l Wildlife Fed’n, 497 U.S. 871, 882 (1990).

41 Methow Valley Citizens Council, 490 U.S. 332, 350 (1989).

42 NEPA Litigation RePoRT, supra note 14; see also U.S. Gov’T ACCOUNTABility OFFICE, supra note 9 , at 19-22.

43 See, e.g., Amanda M.A. Miner et al., Twenty Years of Forest Service National Environmental Policy Act Litigation, 12 ENVTL. PRAC. 116, 118, 122 (2010) (examining NEPA litigation in which the Forest Service was a defendant, in lawsuits filed between 1989 and 2008); Shorna R. Broussard \& Bianca D. Whitaker, The Magna Charta of Environmental Legislation: A Historical Look at 30 Years of NEPA-Forest Service Litigation, 11 FOREST POL'Y \& ECON. 134, 135 (2009) (examining the "litigants, success rates, and management activities disputed for NEPA litigation involving the Forest Service from 1970 to 2001" and examining "differences and patterns in cases ... among the U.S. District, U.S. Circuit Court of Appeals, and U.S. Supreme Court.").

44 Forest SERV., U.S. DeP’T OF AGRIC., LAND AREa of the National Forest System (2017).

4516 U.S.C. $\S 528$ (2012).

46 See infra Part IV.B.6. 
Other articles focus on the seventeen NEPA cases decided by the U.S. Supreme Court. 47 Recent NEPA litigation scholarship focuses on the impacts of the political ideology of judges and presidential administrations on the outcomes of NEPA litigation, using an independently created database of cases from 2001 through 2015.48 These articles utilize data gathered and coded by the authors or other independent sources. We are not aware of any academic articles relying on the NEPA litigation data reported by the CEQ, as this Article does. ${ }^{49}$

\section{NEPA Critics' Calls for Reform}

Numerous bills were introduced during the 115th Congress that would have limited judicial review of NEPA decisions. ${ }^{50}$ H.R. 527, for example, directed that requirements imposed pursuant to NEPA could not preclude actions impacting the greater sage grouse, and exempted those decisions from judicial review. ${ }^{51}$ While unsuccessful, ${ }^{52}$ such efforts indicate sustained interest in reducing the NEPA compliance burden.

Apart from congressional action, Presidential action can influence the NEPA process. President Trump issued an Executive Order in 2017

47 See Richard J. Lazarus, The National Environmental Policy Act in the U.S. Supreme Court: A Reappraisal and a Peek Behind the Curtains, 100 GEO. L.J. 1507, 1510 (2012); Richard J. Lazarus, The Power of Persuasion Before and Within the Supreme Court: Reflections on NEPA's Zero for Seventeen Record at the High Court, 2012 U. ILL. L. REV. 231, 236 (2012).

48 Adelman \& Glicksman, supra note 12 , at $7-9$. The authors of this article created and coded a database of published and unpublished cases issued between 2001 and 2015, drawn from PACER and Westlaw. Id. at 66-67.

49 In addition to articles examining NEPA litigation, several articles examine the substantive effects of agencies' NEPA reviews (prior to and regardless of litigation) on environmental outcomes of agency projects and plans. But these articles evaluate only a narrow range of agency projects and plans in a limited geographic area. See John Ruple \& Mark Capone, NEPA-Substantive Effectiveness Under a Procedural Mandate: Assessment of Oil and Gas EISs in the Mountain West, 7 GEO. WASH. J. ENERGY \& ENVTL. L. 39, 39-41 (2016); John Ruple \& Mark Capone, NEPA, FLPMA, and Impact Reduction: An Empirical Assessment of BLM Resource Management Planning and NEPA in the Mountain West, 46 EnvTL. L. 953, 958-59 (2016); Mark K. Capone \& John C. Ruple, NEPA and the Energy Policy Act of 2005 Statutory Categorical Exclusions: What are the Environmental Costs of Expedited Oil and Gas Development?, 18 VT. J. ENVTL. L. 371, 384 (2017). Other scholarship discusses the procedural efficiencies in the NEPA administrative processes, prior to litigation. DANIEL R. MANDELKER ET AL., NEPA LAW AND LiTIGATION § 11:1 (2d ed. 2019).

50 See, e.g., S. 2068, 115th Cong. § 314 (2017); S. 879, 115th Cong. § 106 (2017); H.R. 2936, 115th Cong. § 311 (2017); and H.R. 875, 115th Cong. § 4 (2017) (all authorizing the Secretary of Agriculture to require arbitration in lieu of judicial review of NEPA Actions); H.R. 4423, 115th Cong. § 2 (2017); S. 3202, 115th Cong. § 2 (2017); H.R. 4419, 115th Cong. $\S 4-5$ (2017) (all shortening the statute of limitations for challenging NEPA claims).

51 Greater Sage Grouse Protection and Recovery Act of 2017, H.R. 527, 115th Cong. (2017); see also S. 273, 115th Cong. (2017).

52 H.R. 527 (115th): Greater Sage Grouse Protection and Recovery Act of 2017, GovTRACK, https://www.govtrack.us/congress/bills/115/hr527 (last visited Jan. 31, 2020); S. 273 (115th): Greater Sage-Grouse Protection and Recovery Act of 2017, GovTRACK, https://www.govtrack.us/congress/bills/115/s273/details (last visited Jan. 31, 2020). 
purporting to "streamline" NEPA's administrative processes by requiring, among other things, that EISs be completed in less than two years from publication of the NOI. ${ }^{53}$ Following President Trump's Executive Order, federal agencies signed a Memorandum of Understanding to implement the Order, ${ }^{54}$ and the CEQ published an Advanced Notice of Proposed Rulemaking in anticipation of proposing amendments to NEPA. ${ }^{55}$

It has been more than thirty years since CEQ's NEPA regulations were last revised, ${ }^{56}$ and much has changed over the intervening decades. We recognize that improvements in NEPA efficacy could be obtained by updating NEPA's implementing regulations. We fear, however, that amendments that are not grounded in an understanding of NEPA practice may result in changes that could undermine our national environmental and public health goals ${ }^{57}$ while doing little to reduce the costs involved in NEPA compliance. The analysis that follows is our effort to illuminate the decisions ahead with regard to judicial review of NEPA decisions.

\section{DATA}

This Article focuses on federal court litigation challenging NEPA decisions. The vast majority of decisions addressed herein occurred at the district court level, though appellate litigation, including litigation before the U.S. Supreme Court, did occur. ${ }^{58}$

While litigation involving NEPA often involves other areas of substantive law such as the Endangered Species Act, ${ }^{59}$ National Forest Management Act, ${ }^{60}$ Federal Land Policy and Management Act, ${ }^{61}$ the Clean Water Act, ${ }^{62}$ and other statutes, this Article focuses on the outcomes of the NEPA claims and does not examine the outcome of substantive law claims raised under other statutes. We acknowledge

53 Exec. Order No. 13807, 82 Fed. Reg. 40,463 (Aug. 24, 2017) (Establishing Discipline and Accountability in the Environmental Review and Permitting Process for Infrastructure Projects).

54 DeP'T OF INTERIOR ET AL., MEMORANDUM OF UNDERSTANDING IMPLEMENTING ONE Federal Decision Under Executive Order 13807 (Apr. 9, 2018), https://perma.cc/WE5Q-U34A.

55 Update to the Regulations for Implementing the Procedural Provisions of the National Environmental Policy Act, 83 Fed. Reg. 28,591 (proposed June 20, 2018).

56 See National Environmental Policy Act Regulations; Incomplete or Unavailable Information, 51 Fed. Reg. 15,618 (Apr. 25, 1986) (amending 40 C.F.R. § 1502.22).

57 See 42 U.S.C. $\$ 4321$ (2012).

58 Little statistical information is available regarding administrative protests or appeals of NEPA decisions, which could precede district court litigation. Administrative challenges are not addressed in this Article.

5916 U.S.C. $\$ \S 1531-1544$ (2012).

6016 U.S.C. $\S \S 472 \mathrm{a}, 521 \mathrm{~b}, 1600,1611-1614$ (2012) (amending Forest and Rangeland Renewable Resources Planning Act of 1974, Pub. L. No. 93-378, 88 Stat. 476 (1974)).

6143 U.S.C. §§ 1701-1787 (2012).

62 Federal Water Pollution Control Act, 33 U.S.C. $§ \S 1251-1388$ (2012). 
that it is also possible for an agency to prevail on other grounds only to lose on NEPA compliance. ${ }^{63}$ At the same time, an agency may win on a NEPA claim but lose the case because of a violation of another statute. ${ }^{64}$ Accordingly, where claims are brought under multiple statutes, criticisms focused on litigation may not distinguish between statutes, and this could result in overstatement of the NEPA litigation burden, if NEPA becomes a surrogate for all environmental laws. ${ }^{65}$

\section{A. CEQ NEPA Production and Litigation Data}

Data on NEPA litigation came from reports compiled by the CEQ that were published annually between 2001 and 2013. These reports "identify the number of cases involving a NEPA-based cause of action, federal agencies that were identified as a lead defendant, general information on plaintiffs, general information on why litigation was pursued, and the outcomes of the cases decided during the year." $66 \mathrm{We}$ combined the data from each annual CEQ published report into a single spreadsheet in order to track trends over time and analyze averages for the thirteen year period. ${ }^{67}$

63 See, e.g., Diné Citizens Against Ruining Our Env’t v. Bernhardt, 923 F.3d 831, 849, 859 (10th Cir. 2019) (holding that BLM was successful on its National Historic Preservation Act claims but lost on NEPA).

64 Miner et al., supra note 43, at 122.

65 However, one study focused on Forest Service litigation found that only in about one in ten NEPA lawsuits did the agency prevail on NEPA grounds while losing on other statutory requirements. Miner et al., supra note 43 , at 122 . We are not aware of any studies testing if this finding holds true across other agencies besides the Forest Service. This study examined Forest Service litigation between 1989 and 2008 and found that, in cases where the court specifically ruled on a NEPA challenge (as opposed to withdrawals or dismissals), the Forest Service "won the NEPA claim, but lost the case because of a violation of another statute or statutes" in $7.5 \%$ of studied cases (or $10.9 \%$ of the NEPA wins). Id.

66 See NEPA LiTIGATION REPORT, supra note 14 (compilation of annual surveys from 2001-2013). For the individual annual surveys for 2001-2011, see NEPA Litigation Surveys, OFFICE OF NEPA POL'Y \& COMPLIANCE, https://perma.cc/V7TE-M5XP (last visited Apr. 18, 2020).

67 The CEQ's published reports contained discrepancies in the summary data. We also identified gaps in agency-level information on the number of government "wins" and "settlements," the types of NEPA documents each agency most often saw challenged in court, and each agency's success rates in litigation on each type of document. The CEQ's published reports provided "win" and "settle" data on a governmentwide level, but not on an agency level. The CEQ's published data did, however, include agency-level "losses," i.e. injunctions and remands. See NEPA LITIGATION REPORT, supra note 14. We worked with the CEQ to resolve questions regarding the summary data. We also obtained and reviewed the CEQ's raw data, which tracks and codes every NEPA case between 2001 and 2013. We ultimately concluded that we could not make agency-level calculations on the type of NEPA review at issue in litigation and each agency's litigation success rates for each type of NEPA review. We were, however, able to calculate agency-level numbers of "wins" and "losses" generally for all kinds of NEPA litigation using the CEQ's coding. While we were unable to completely reconcile all discrepancies with the CEQ summary data, we believe that our final dataset is more than adequate to identify broad trends in NEPA litigation. 
We used the CEQ data to examine the number of NEPA lawsuits filed, the number and types of NEPA documents challenged, and the outcomes of NEPA litigation, 68 including the number of NEPA lawsuits that were disposed of based on the adequacy of an EIS or SEIS. ${ }^{99}$ These results reflect the data as reported by the CEQ and federal agencies. ${ }^{70}$

In addition to the data referenced above on NEPA litigation, the CEQ recently released a database containing start and end dates for 1,161 EISs completed between 1992 and 2018.71 Specifically, that database includes the publication dates for the NOI, Draft EIS, Final EIS, and ROD as well as the amount of time that passed between each phase of EIS preparation. We used this data in order to investigate the potential relationship between the amount of time spent on EIS preparation and litigation.

\section{B. EPA EIS Filing Data}

The EPA publishes in the Federal Register a notice of availability for every Draft, Final, and Supplemental EIS.72 This information is stored in an online database that can be searched based on the date of the notice, the lead agency responsible for preparing the EIS, and the state where the proposed action would occur. ${ }^{73}$ We used this database to determine the universe of Final EISs that would potentially be subject to litigation as well as the total number of EISs produced by each agency during the analysis period.

While the EPA dataset provides a complete record of EISs, there is not a similar repository of statistics on other types of NEPA documents (EAs and CEs). The lack of a centralized repository of NEPA documents, or even a record of the number of NEPA actions by agency, is problematic because an estimated 99\% of all NEPA reviews occur via CEs and EAs. ${ }^{74}$

Any NEPA reform should begin with an effort to better understand the universe of NEPA actions. The BLM's ePlanning website, which includes a database of all BLM NEPA decisions that is searchable by

68 The NEPA Litigation CEQ Reports refer to this type of data as the "NEPA Case Dispositions."

69 The NEPA Litigation CEQ Reports refer to this type of data as the "Basis for NEPA Disposition."

70 Although we were unable to independently verify how the CEQ data was coded, we used the data as reported by the government. CEQ data was not accompanied by a data dictionary, and without a clear explanation of CEQ's assumptions or methods, we feared that our uninformed efforts to recode data could increase rather than resolve coding issues. While errors may exist, we believe that the dataset is sufficient to identify broad trends in NEPA litigation. We also believe that relying on CEQ data will serve as an important complement to other articles that use independently coded data.

71 See CEQ EIS TIMELINES, supra note 8.

7240 C.F.R. $\$ 1506.10$ (a) (2018); see also EPA EIS Database, supra note 36 (containing records of all EISs prepared by all federal agencies since 1987).

73 EPA EIS Database, supra note 36.

74 U.S. GOV'T ACCOUNTABILITY OFFICE, supra note 9, at 8. 
date, project type, and level of NEPA analysis, 75 is an example of a positive step in this direction. Reform divorced from a clear understanding of the actions being amended is likely to have limited benefits and could have unintended negative consequences.

\section{U.S. Attorneys' Office Federal Environmental Litigation Data}

The Executive Office for U.S. Attorneys annually publishes statistics summarizing federal litigation involving the U.S. government. 76 These reports indicate the number of cases involving the federal government that were filed, terminated, or that remain pending by year. ${ }^{77}$ Civil litigation involving the United States is further broken down by cases in which the federal government is a defendant or plaintiff, and by categories of cause of action. ${ }^{78}$ Relying on this data, we were able to quantify the number of civil actions and "environmental/lands" civil actions in which the federal government was a defendant over the 2001-2013 period. We used this data to determine how common NEPA litigation is as a percent of all civil actions filed against the United States, and as a percent of all "environmental/lands" civil actions filed against the United States.

Department of Justice statistics also indicate the number of judgements for the United States, settlements, judgements against the United States, dismissals, and "other" dispositions over the project period. ${ }^{79}$ We divided data for each of these five categories by the number of cases terminated in that year to determine the percent of dispositions by category. We compared this to the CEQ's NEPA litigation data to assess whether the federal government fares similarly in NEPA and non-NEPA civil litigation in which the federal government is a defendant. 80

\section{ANALYSIS OF NEPA LITIGATION}

We conducted a historical analysis of NEPA litigation ${ }^{81}$ in the U.S. federal court system that had an outcome or resolution ${ }^{82}$ between 2001 and 2013. We also tracked cases that remained pending during that

75 ePlanning Project Search, BUREAU LAND MGMT., https://perma.cc/Z5RS-69QJ (last visited Apr. 18, 2020) (online National NEPA Register).

76 Annual Statistical Reports, OFFICE U.S. ATT'Ys, https://perma.cc/8329-LHE6 (last updated Sept. 4, 2019).

77 Id.

$78 I d$.

79 Id.

80 For purposes of this analysis, we assumed that the federal government was a defendant in all NEPA cases.

81 This Article uses the term "NEPA litigation" to refer to cases in which the federal government was a defendant and NEPA was a subject of the litigation.

82 This includes final rulings as well as settlements and temporary relief such as preliminary injunctions. 
period. Part A reviews information on the number and burden of NEPA documents completed annually. Part B examines the burden of NEPA litigation in terms of the frequency with which the government's NEPA documents were challenged in court and which type of NEPA actions were most frequently litigated (CEs, EAs, or EISs). Part C examines the outcomes of NEPA litigation in terms of the government's success rates, which type of NEPA actions are most frequently upheld, and the government's success in NEPA litigation compared to its success in other kinds of litigation.

\section{A. How Burdensome is NEPA Compliance?}

We considered the burden imposed by NEPA compliance in terms of the number of federal actions requiring NEPA analysis annually, and the level of NEPA analysis conducted. We were particularly interested in the share of actions evaluated in an EIS, the most lengthy and expensive process for NEPA compliance. We also examined the time required to complete NEPA analyses. We found that the vast majority of NEPA decisions do not require completion of an EIS and that the number of EISs produced annually has declined steadily. We also found that the time required to complete the NEPA review varies by agency and that agencies that spend less time on their NEPA analysis are sued at higher rates than their more contemplative counterparts.

\section{Number and Types of NEPA Documents Governmentwide}

As noted earlier, the GAO estimates that $95 \%$ of NEPA documents involve CEs, nearly $5 \%$ are EAs, and less than $1 \%$ are EISs. ${ }^{83}$ According to EPA data, there were an average of 513 EISs produced annually between 2001 and 2013. ${ }^{84}$ Extrapolating from the number of EISs prepared annually, we estimate that roughly 2,560 EAs and 48,700 CEs are also prepared annually. ${ }^{85}$ Draft EISs account for slightly more than half of all EISs, at 269 annually. ${ }^{86}$ Final EISs average 239 annually. ${ }^{87}$ The distinction between Draft and Final EIS is important because a Draft EIS is not a final agency action and therefore cannot give rise to litigation.

The number and proportion of total NEPA documents are rough estimates and actual numbers vary considerably by agency. For example, the GAO noted that the Department of Energy (DOE) reported $95 \%$ of its NEPA documents are CEs, $2.6 \%$ were EAs, and $2.4 \%$ were

83 U.S. Gov’t ACCOUNTABILITY OFFICE, supra note 9, at 8.

84 EPA EIS Database, supra note 36.

85 See supra Part II.A.

86 EPA EIS Database, supra note 36 (calculated from data available). These estimates include Revised and Supplemental Final EISs.

${ }^{87}$ Id. These estimates include Revised and Supplemental Final EISs. 
EISs. ${ }^{88}$ The Forest Service reported that $78 \%$ of its NEPA analyses were CEs, $20 \%$ were EAs, and $2 \%$ were EISs. ${ }^{89}$ Beginning in 2015, the BLM began posting its NEPA documents online. ${ }^{90}$ Based on documents published to the BLM's ePlanning website, the BLM prepared EISs for just $0.43 \%$ of all of its NEPA documents, or just 67 EISs out of 15,439 total NEPA documents from 2015 through $2018 .{ }^{91}$ Over that period the BLM relied on EAs $36.5 \%$ of the time, and CEs for $63.1 \%$ of its NEPA decisions. ${ }^{92}$

While differences between agencies are notable, it is clear that EISs remain exceedingly rare, accounting for a very small percentage of all NEPA actions.

\section{EIS Production Trends over Time and By Agency93}

The number of Final EISs ${ }^{94}$ (including Revised and Supplemental Final EISs) produced governmentwide declined over 16\% between 2001 and 2013, from 216 in 2001 to 181 in 2013. The decline, however, has not been steady. The number of Final EISs produced peaked in 2004 at 305 , then oscillated over the next several years along an overall downward trajectory. The fewest number of Final EISs produced over the study period occurred in 2013, with 181 EISs. Final EIS production was below the 13-year average in each of the last five years of the study period. ${ }^{95}$ Annual EIS production is shown in Table 1.

\footnotetext{
88 U.S. GOV’T ACCOUNTABILITY OFFICE, supra note 9, at 8.

89 See id.

90 See BuREau Land MGMT., supra note 75 . Unless noted otherwise, we extrapolated from the GAO's figures in order to estimate the BLM's total NEPA burden. We did not extrapolate from the BLM's figures because of the short period of BLM data (four years) and because we do not know if all BLM NEPA documents were reported on the ePlanning website.

91 See Bureau Land MGMT., supra note 75.

92 See id. Approximately $18 \%$ of all BLM NEPA actions were authorized in a "Determination of NEPA Adequacy," which documents analysis in a prior NEPA document. Id. Determinations of NEPA Adequacy are excluded from the percentage breakdown discussed above because they do not represent a new NEPA analysis or decision.

93 Data for this section is calculated from EPA EIS Database, supra note 36.

94 We narrow our focus in this section to Final EISs (as opposed to also including Draft EISs) because a Draft EIS is not a final agency action subject to judicial review, and NEPA litigation is the ultimate focus of this Article.

95 We limit our analysis to EISs produced through 2013 to maintain consistency with CEQ litigation data but note that the number of Final EISs produced was below the 13 year average each year from 2014 through 2017. See EPA EIS Database, supra note 36.
} 


\begin{tabular}{|c|c|c|c|c|c|c|c|c|c|c|c|c|c|c|c|}
\hline & 2001 & 2002 & 2003 & 2004 & 2005 & 2006 & 2007 & 2008 & 2009 & 2010 & 2011 & 2012 & 2013 & Total & Mean \\
\hline $\begin{array}{c}\text { Draft and } \\
\text { Supplemental } \\
\text { Draft EISs }\end{array}$ & 275 & 282 & 316 & 304 & 292 & 295 & 290 & 271 & 256 & 247 & 237 & 208 & 217 & 3,490 & 268 \\
\hline $\begin{array}{c}\text { Final and } \\
\text { Supplemental } \\
\text { Final EISs }\end{array}$ & 216 & 251 & 261 & 305 & 254 & 252 & 260 & 281 & 208 & 248 & 204 & 211 & 181 & 3,132 & 241 \\
\hline $\begin{array}{c}\text { Other EISs } 96 \\
\text { Total }\end{array}$ & 5 & 5 & 4 & 7 & 5 & 4 & 7 & 1 & 0 & 1 & 2 & 0 & 0 & 41 & 3 \\
\hline \hline
\end{tabular}

Table 1: EISs Completed, 2001-2013 ${ }^{97}$

EIS production and trends varied by agency. Among the four primary federal land management agencies, the Forest Service produced $26 \%$ of all Final and Supplemental Final EISs governmentwide, averaging almost 63 annually. The BLM produced $8.3 \%$ of all Final and Supplemental Final EISs, averaging 20 per year over the 13-year period. The National Park Service (NPS) produced 5.9\% of Final and Supplemental Final EISs governmentwide, averaging 14.2 per year. The Fish and Wildlife Service produced only 2.6\% of Final and Supplemental Final EISs governmentwide, with an annual average of 6.2 over the 13year period.

As shown in Figure 1, the Forest Service's production of Final and Supplemental Final EISs declined over the study period, falling to 40 EISs in 2013; well below the 13-year average of 62.7 EISs per year. Similarly, the NPS reduced its Final EIS production over the 13-year period to 10 in 2013; down from an average of 14.2 EISs annually. In contrast, the Fish and Wildlife Service and the BLM both increased their Final EIS production over the 13-year period. The Fish and Wildlife Service produced an average of 6.2 Final and Supplemental Final EISs annually from 2001 through 2013 and completed 10 EISs in 2013. The BLM completed 19 Final or Supplemental Final EISs in 2013, which was down slightly from its average of 19.9 EISs annually, but overall, the BLM saw a slight increase in EIS production over the study period.

96 The EPA database included several abbreviations for EIS types (e.g., LF, LD, DD, $\mathrm{DE}$, and DF) that we were not confident in recoding. These abbreviation EIS types are coded as "other."

97 See EPA EIS Database, supra note 36. 


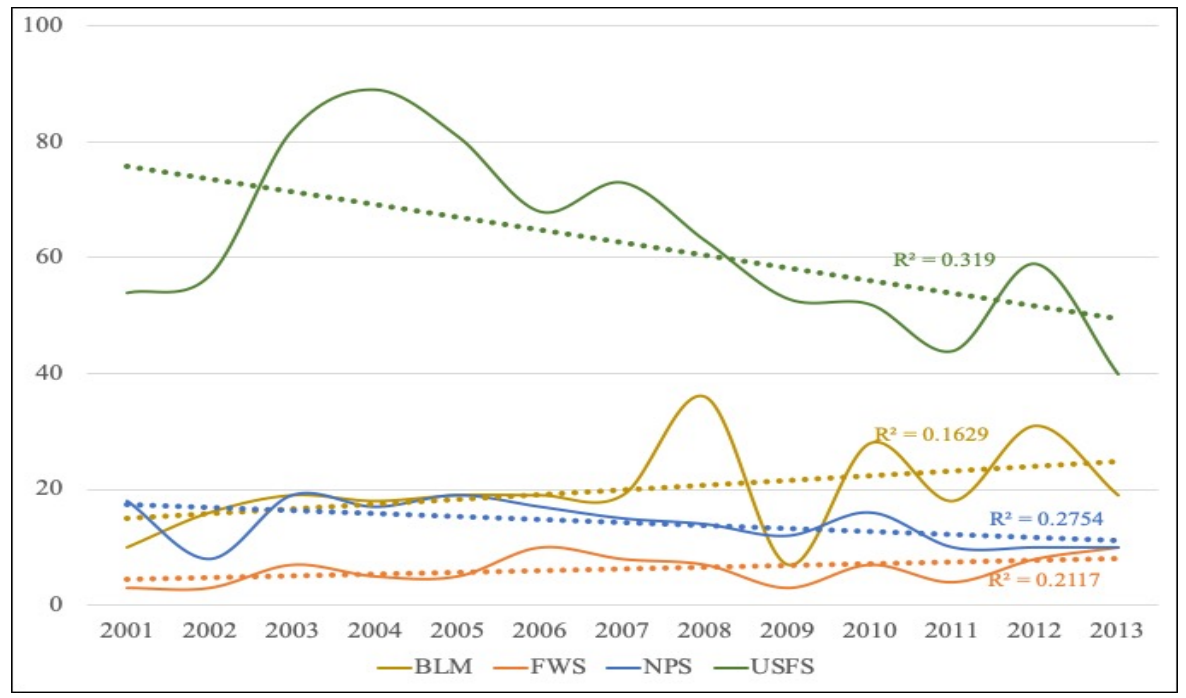

\section{Figure 1: Final and Supplemental EIS Filings for the Four Primary Land Management Agencies, 2001-2013 98}

Overall, the four primary land managers experienced a decline in EIS production $\left(\mathrm{R}^{2}=0.092\right)$ over the study period, producing a combined total of just 79 Final or Supplemental Final EISs during 2013, down from an average of 103 per year. ${ }^{99}$ While the cause of this decline is uncertain, it may be that agencies are becoming more efficient in tiering to other NEPA documents, ${ }^{100}$ a practice that could facilitate the use of EAs and Mitigated FONSIs. ${ }^{101}$ If this is the case, it would appear that agencies have become more effective at reducing environmental impacts, which is one of NEPA's primary goals. ${ }^{102}$ It would also show progress in paperwork reduction and reducing delays that result from reducing the number of decisions subject to the most demanding level of analysis. ${ }^{103}$

98 See EPA EIS Database, supra note 36 (data limited to EISs produced through 2013).

99 See 40 C.F.R. $§ 1500.4-.5$ (2018) (identifying paperwork reduction and reducing delays as regulatory goals).

100 "Tiering" is the practice of covering broader matters in an EIS and incorporating that analysis into subsequent NEPA documents by reference in order to focus the subsequent analysis. See id. $\S 1500.4(i)$.

101 A mitigated FONSI incorporates required mitigation designed to ensure that project impacts remain below the threshold of significance. See Forty Most Asked Questions Concerning CEQ's National Environmental Policy Act Regulations, 46 Fed. Reg. 18,026, 18,037-38 (Mar. 23, 1981) (questions 39 and 40).

$102 \mathrm{R}^{2}$ is a statistical measure of how much variation in the dependent variable is explained by the independent variable. For the decline in the number of Final EISs produced by the four main land management agencies, annual change explained just $9.2 \%$ of the overall reduction while explaining $31.9 \%$ of the decline by the BLM. See EPA EIS Database, supra note 36.

103 See NEPA, 42 U.S.C. § 4321 (2012). Other goals include encouraging public involvement and transparency. Id. 


\section{The Timing of NEPA Compliance}

Timeframes for completing a NEPA review vary dramatically based upon the agency and type of review completed. A CE, for example, can take as little as one to two days to complete, as reported by the DOE and the Department of the Interior's Office of Surface Mining, while the Forest Service reports taking an average of 177 days to complete CEs. ${ }^{104}$ EAs take longer to complete, ranging from one month for the Bureau of Indian Affairs, four months for the Department of Interior's Office of Surface Mining, and 13 months for the DOE, to 18 months for the Forest Service. ${ }^{105}$

Across all federal agencies, EISs take the longest and have the greatest variability in completion times, with a median of 3.6 years and an average (mean) of 4.5 years from the time of issuance of an NOI to publication of a ROD. 106 The fastest $25 \%$ of EISs took less than 2.2 years to complete, and the fastest EIS completion time overall was one year (achieved by 36 out of 1,161 EISs between 2010 and 2017). ${ }^{107}$ By contrast, the slowest $25 \%$ took more than 6.0 years to complete, with longest overall completion time being over 17 years (experienced by only 4 out of 1,161 EISs). ${ }^{108}$ However, this data does not indicate how much work was completed before the NOI, whether these timeframes include suspensions of work on an EIS, or the reasons for lengthy completion times. Many intervening factors are beyond the agency's control, such as changes proposed by the applicant, funding limitations, delays to complete required surveys or studies, or shifting federal or agency priorities. 109 For example, Yucca Mountain, the proposed long-term repository for high-level nuclear waste, has been mired in political controversy for decades. ${ }^{110}$ While NEPA analysis for that project has languished, these delays appear to say more about scientific uncertainty and the underlying political conflict than extreme cases such as this do about NEPA, and they may skew average EIS completion times.

Average EIS completion time also varies considerably by agency. The Forest Service had faster than typical EIS completion times, with a median of 2.92 years and a mean of 3.35 years. ${ }^{111}$ The National Oceanic and Atmospheric Administration (NOAA) was also faster than the governmentwide norms for EIS completion, with a median of 2.79 years

104 U.S. GOV'T ACCOUNTABILITY OFFICE, supra note 9, at 16.

105 Id. at $15-16$.

106 CEQ EIS TIMELINES, supra note 8, at 4 fig.1.

107 Id.

$108 \mathrm{Id}$.

109 Id. at 2; see also LiNDA Luther, CONG. RESEARCh SERV., RL33267, THE NATIONAL Environmental Policy ACT: STREAMLINING NEPA 8-9 (2007) (discussing sources of delays for federal projects).

110 U.S. Nuclear Reg. Comm’n, Licensing Yucca Mountain 2-3 (2018), https://perma.cc/QLQ9-SKVY; see also 153 CON. REC. 5813 (2007) (statement of Rep. Berkley).

111 CEQ EIS Timelines, supra note 8, at 8 fig.5, 12 fig.6. 
and a mean of 3.59 years. ${ }^{112}$ The BLM's EIS completion time hovered around the governmentwide norms, with a median of 3.83 years and a mean of 4.41 years. ${ }^{113}$ The Fish and Wildlife Service had slightly longer than average EIS completion times, with a median of 4.23 years and a mean of 4.64 years. ${ }^{114}$ The NPS was in the slowest quartile, with a median of 6.35 years and a mean EIS completion time of 6.72 years. ${ }^{115}$ Other comparatively slow agencies include Army Corps of Engineers, with an median EIS completion time of 5.16 years and a mean of 6.13 years; the Federal Aviation Administration with a median of 6.63 years and a mean of 7.72 years; and the Federal Highway Administration with a median of 6.85 years and a mean of 7.3 years. ${ }^{116}$

Litigation that follows completion of a NEPA document can also add to the time-cost of NEPA compliance. The CEQ's NEPA Litigation Reports, the primary data source for this Article, do not provide information on how long individual court cases took. However, a recent article on NEPA litigation estimated that the median duration of NEPA litigation is 23 months, and $75 \%$ of cases were resolved within 3.2 years. ${ }^{117}$ For the cases in which the government won, the median case only took 1.5 years. ${ }^{118}$ We have not, however, found data reporting on variation in the temporal duration of NEPA lawsuits that distinguish between CEs, EAs, and EISs.

\section{EIS Production Time Compared to Litigation Rates}

Professors Adelman and Glicksman recently calculated the ratio between the percent of EISs produced by an agency, as a share of the total governmentwide number of EISs, and that agency's share of EIS litigation governmentwide. ${ }^{119}$ This allowed the professors to determine the rate at which agencies' EISs are challenged in court compared to the number of EISs they produced. The higher the ratio, the more likely the agency is to face litigation over an EIS. The BLM, for example, prepared $11.6 \%$ of all EISs and was the subject of $11.4 \%$ of all EIS litigation, resulting in a multiplier of one, meaning that the amount of EIS litigation faced by the BLM was proportionate to the number of EISs it prepared. ${ }^{220}$ The Forest Service, by comparison, produced $21.7 \%$ of all EISs and was involved in $30.8 \%$ of EIS litigation, generating a multiplier of 1.4, meaning that the number of EIS challenges faced by the Forest Service was roughly $40 \%$ higher than expected based on the

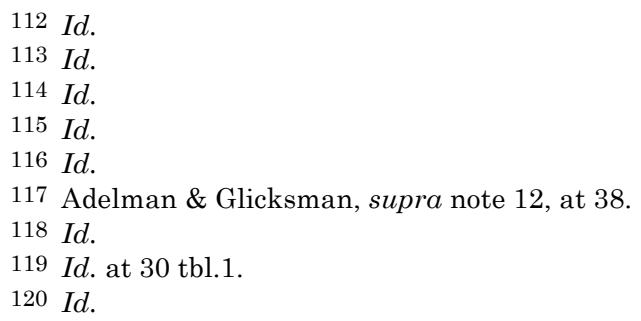


number of EISs the agency prepared. ${ }^{121}$ Other agencies were sued at a rate disproportionate to the number of EISs they produced. As shown in Table 2, the Fish and Wildlife Service (the FWS) has a litigation ratio of 1.8 , indicating that they are sued approximately $80 \%$ more often than would be expected based on the number of EISs they prepare. ${ }^{122}$ The Federal Highway Administration, conversely, has a litigation ratio of 0.3 , indicating that they are sued at about one-third the rate of their peers. ${ }^{123}$

Based on our examination of Professors Adelman and Glicksman's EIS litigation-ratio data and the CEQ's EIS production timeline data, both described above, we observed that the amount of time spent on EIS preparation appears to be inversely related to the likelihood that an EIS will be challenged in court. ${ }^{124}$ For example, the Forest Service spends an average of 1.13 years less on EIS preparation and is sued at a much higher rate than its sister agencies. ${ }^{125}$ The Federal Energy Regulatory Commission (FERC) also proceeds faster than average and is sued at an above average rate. ${ }^{126}$ The Army Corps of Engineers and Federal Highway Administration take considerably more time to prepare an EIS and are sued at much lower rates. ${ }^{127}$ Rapid EIS preparation therefore appears correlated with an increased risk of litigation.

\section{Id.}

122 Id.

$123 \mathrm{Id}$.

124 The relationship between EIS preparation time and litigation rates was not statistically significant $(p=0.2089)$. The lack of statistical significance was anticipated because of the small number of agencies for which we have litigation ratios.

125 See supra note 111 and accompanying text; see also infra Table 2.

126 FERC's mean time from the NOI to ROD on an EIS is 2.67 years and its median time is 2.29 years. CEQ EIS TIMELINES, supra note 8, at 10 fig. 5, 14 fig. 6 .

127 See supra note 116 and accompanying text; see also infra Table 2. 


\begin{tabular}{|c|c|c|c|c|c|c|}
\hline & $\begin{array}{c}\text { Number of EISs } \\
\text { Completed }\end{array}$ & $\begin{array}{c}\text { NOI- } \\
\text { DEIS } \\
\text { (Years) }\end{array}$ & $\begin{array}{c}\text { DEIS-FEIS } \\
\text { (Years) }\end{array}$ & $\begin{array}{c}\text { FEIS-ROD } \\
\text { (Years) }\end{array}$ & $\begin{array}{c}\text { NOI-ROD } \\
\text { (Years) }\end{array}$ & $\begin{array}{c}\text { Litigation } \\
\text { Ratio }{ }^{128}\end{array}$ \\
\hline $\begin{array}{c}\text { Army Corps of } \\
\text { Engineers }\end{array}$ & 89 & 3.3 & 0.9 & 0.5 & 5.2 & 0.5 \\
\hline $\begin{array}{c}\text { Dep't of Defense } \\
\text { (w/o Corps of } \\
\text { Engineers) }\end{array}$ & 76 & 1.5 & 1.0 & 0.2 & 3.1 & 0.6 \\
\hline Dep't of Energy & 16 & 1.6 & 0.8 & 0.2 & 2.7 & 0.7 \\
\hline BLM & 128 & 2.0 & 1.1 & 0.3 & 3.8 & 1.0 \\
\hline FWS & 40 & 2.4 & 1.0 & 0.2 & 4.2 & 1.8 \\
\hline $\begin{array}{c}\text { Fed. Highway } \\
\text { Admin. }\end{array}$ & 114 & 3.5 & 2.1 & 0.2 & 6.9 & 0.3 \\
\hline $\begin{array}{c}\text { Fed. Energy Reg. } \\
\text { Comm'n }\end{array}$ & 34 & 1.3 & 0.5 & 0.3 & 2.3 & 1.1 \\
\hline Forest Serv. & 276 & 1.4 & 0.9 & 0.1 & 2.9 & 1.4 \\
\hline \hline All Agencies & 1,161 & 1.9 & 1.0 & 0.2 & 3.6 & 1.0 \\
\hline
\end{tabular}

Table 2: Median Time to Complete an EIS \& Likelihood of Litigation 2010-2017

Together the BLM, Forest Service, FERC, Army Corps of Engineers, and Federal Highway Administration account for almost $83 \%$ of the EISs for which we have litigation ratio data (see Table 2). ${ }^{129}$ We recognize that a number of factors may influence the rate at which an agency prepares its NEPA documents, including an agency's approach to NEPA analysis, agency resources, effort preceding publication of an NOI, the complexity of projects, and changes attributable to a non-agency project proponent. Nonetheless, the apparent relationship between rapid EIS preparation time and subsequent litigation should caution those seeking to expedite EIS preparation. With NEPA litigation taking an average of 23 months, ${ }^{130}$ gains in preparation time could be more than offset by litigation delays, should litigation occur. An adverse legal ruling will only compound those delays. The benefits gained by expediting NEPA may, in short, be subsumed by even greater costs associated with NEPA litigation.

\section{B. How Burdensome is NEPA Litigation?}

We examined the burden posed by NEPA litigation on various agencies and the federal government as a whole by analyzing: 1) the number of NEPA lawsuits filed annually;131 2) NEPA lawsuit filings compared to other civil suits against the federal government;132 3) the

128 Litigation ratio is the agency's share of EISs produced (compared to all agencies) versus the agency's share of EIS litigation (compared to all agencies). See supra note 119 and accompanying text.

129 We calculated this by dividing the total number of EISs prepared by these five agencies (641) by the total for the eight agencies specifically listed in Table 2 (773).

130 See supra note 117 and accompanying text.

131 See infra Part IV.B.1. The data comes from NEPA LITIGATION REPORT, supra note 14. CEQ calls the data on NEPA lawsuits "Cases Filed."

132 See infra Part IV.B.2. 
percentage of all NEPA documents challenged in court;133 4) the type of NEPA documents challenged;134 5) the frequency with which EISs and Supplemental EISs are challenged; ${ }^{135}$ and 6) differences in the NEPA litigation burden between agencies. ${ }^{136}$

We found that very few NEPA decisions are challenged in court and that the rate at which NEPA decisions are challenged is declining. We also found that NEPA challenges declined faster than the rate at which agencies prepare EISs, which is also declining. Additionally, NEPA litigation is declining as a percent of environmental litigation against the federal government, while general civil litigation against the federal government is on the rise. These findings, we believe, call into question claims that NEPA litigation is unreasonably burdensome and that environmental organizations use NEPA indiscriminately in order to stop or delay federal actions.

\section{NEPA Lawsuit Filing Trends Governmentwide}

As noted in Part II.A., we conservatively estimate that the federal government prepares approximately 51,300 NEPA documents and 51,000 NEPA decisions annually. ${ }^{137}$ Despite the large number of NEPA documents, there are on average just 115 NEPA lawsuits filed every year governmentwide, ${ }^{138}$ which represents a litigation rate of $0.22 \%$ - or roughly one out of every 450 NEPA decisions.

The number of NEPA case filings is also in decline, with some yearly variation. There were 138 NEPA suits filed in 2001, and 96 NEPA suits filed in 2013. NEPA lawsuits peaked in 2004 at 166, the same year as the peak number of Final EISs produced. The fewest lawsuits were filed in 2007, with just 86 NEPA lawsuits filed governmentwide. While filings varied by year, each of the last five years experienced below-average NEPA case filings and a clear downward trend in litigation filings, which can be seen in Table 3 and Figure 2.

133 See infra Part IV.B.3.

134 See infra Part IV.B.4.

135 See infra Part IV.B.5.

136 See infra Part IV.B.6.

137 See supra note 39 and accompanying text. The number of documents and decisions differ slightly because more than half of all EISs are drafts and therefore do not reflect a final decision.

138 Compilation of data from NEPA LITIGATION REPORT, supra note 14. 


\begin{tabular}{|c|c|c|c|c|c|c|c|c|c|c|c|c|c|c|c|}
\hline & 2001 & 2002 & 2003 & 2004 & 2005 & 2006 & 2007 & 2008 & 2009 & 2010 & 2011 & 2012 & 2013 & $\begin{array}{c}\text { Total } \\
\text { Filed }\end{array}$ & $\begin{array}{c}\text { Annual } \\
\text { Mean }\end{array}$ \\
\hline $\begin{array}{c}\text { All } \\
\text { Agencies }\end{array}$ & 138 & 147 & 140 & 166 & 120 & 108 & 86 & 132 & 97 & 87 & 94 & 88 & 96 & 1,499 & 115.3 \\
\hline $\begin{array}{c}4 \text { Federal } \\
\text { Land } \\
\begin{array}{c}\text { Management } \\
\text { Agencies }\end{array}\end{array}$ & 84 & 74 & 84 & 104 & 69 & 57 & 52 & 72 & 44 & 43 & 55 & 54 & 65 & 857 & 65.9 \\
\hline
\end{tabular}

Table 3: NEPA Case Filings 2001-2013 139

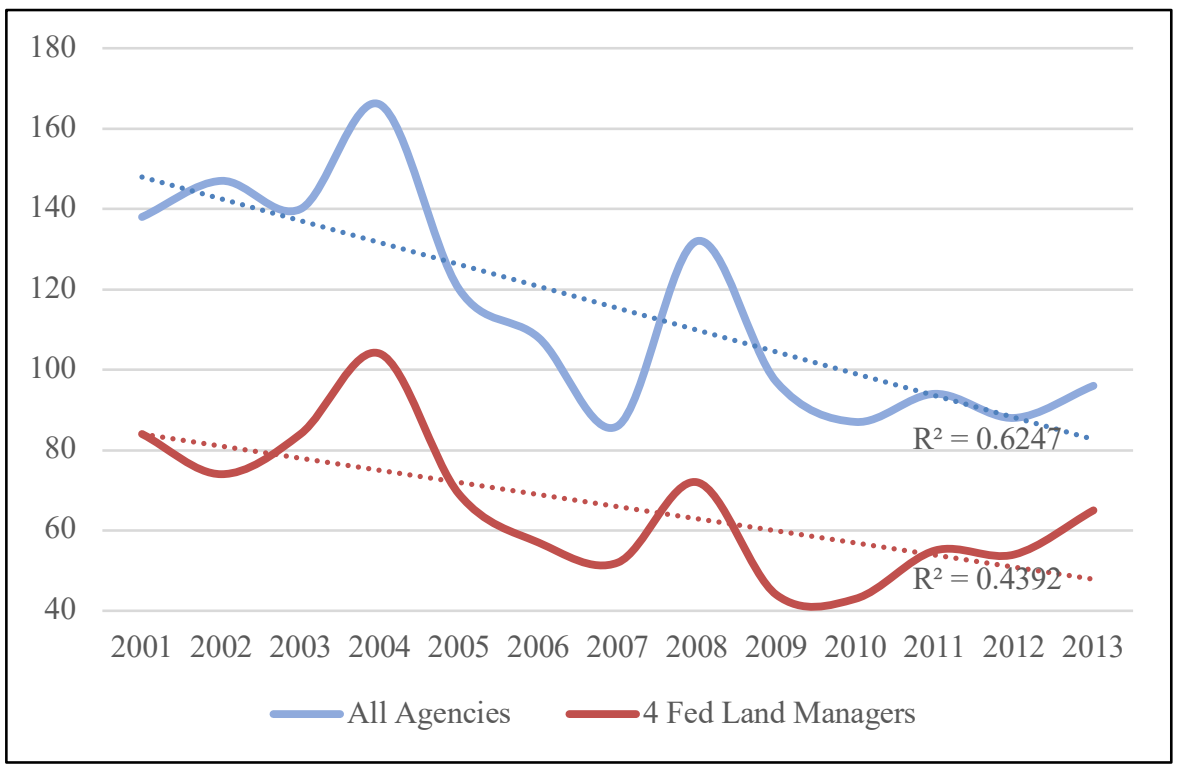

Figure 2: NEPA Case Filings 2001-2013

This governmentwide trend in NEPA lawsuit filings represents a $30.4 \%$ reduction over the study period $\left(\mathrm{R}^{2}=.6247\right)$. NEPA challenges involving the four primary federal land management agencies (the BLM, Forest Service, Park Service, and the FWS) also declined steadily, but at a slightly slower pace, $22.6 \%$, over the same period of time $\left(\mathrm{R}^{2}=.4392\right)$.

139 Compilation of data from NEPA LITIGATION REPORT, supra note 14. 


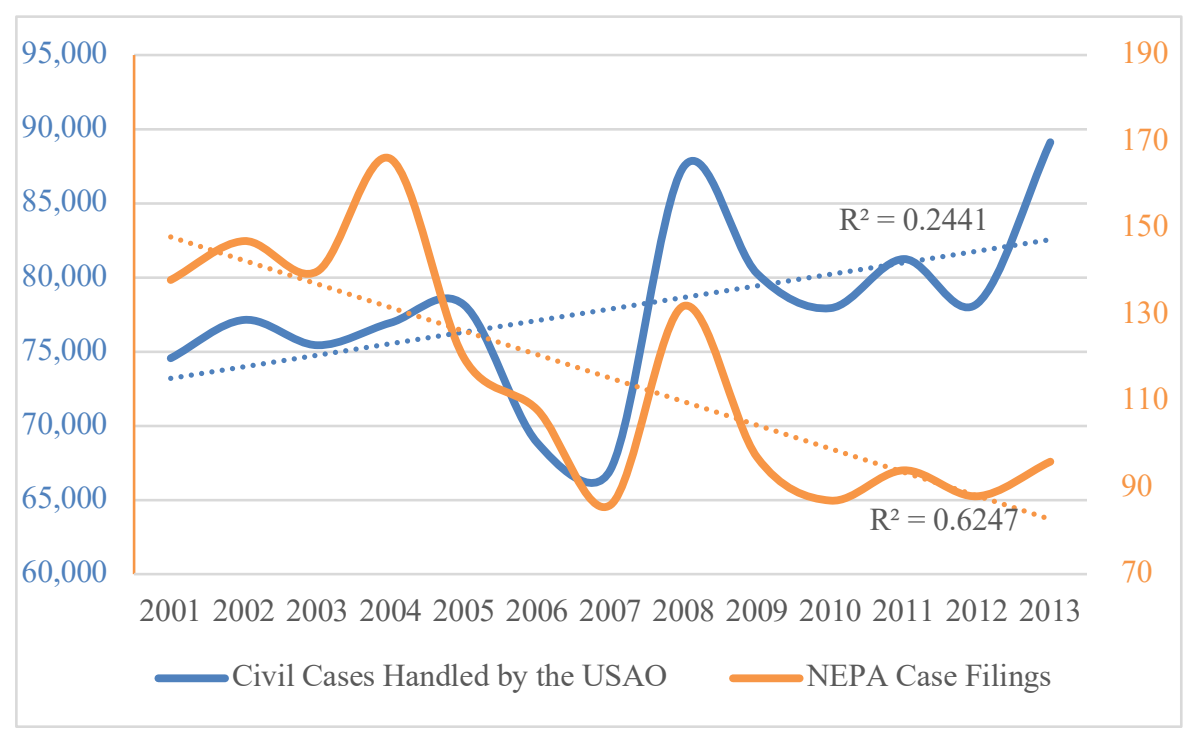

\section{Figure 3: NEPA Case Filings \& Federal District Court Civil Filings Handled by the U.S. Attorneys Office 2001-2013}

The decline in NEPA lawsuit filings cannot be fully explained by trends in EIS production nor general trends in litigation involving the federal government. The $30.4 \%$ decline in NEPA lawsuits filed against the federal government was sharper than the $16 \%$ decline in the number of Final EISs produced during the period studied. ${ }^{140}$ Additionally, the $30.4 \%$ decline in NEPA lawsuits filed during the 13-year study period stands in contrast to a $19.5 \%$ increase in the number of U.S. district court civil cases handled by the U.S. Attorneys Office over that same period. ${ }^{141} \mathrm{~A}$ complete breakdown of court filings by agency is contained in Part IV.B.6. With NEPA litigation declining faster than the rate of EIS production and in the face of increased civil litigation, it appears that the burden of NEPA litigation is declining.

\section{NEPA Lawsuit Filings Compared to All Civil Suits Against the United States}

To understand the relative burden posed by NEPA versus nonNEPA litigation, we compared the number of NEPA lawsuits filed to the total number of civil suits against the federal government. ${ }^{142}$ As shown in Table 4, we found that NEPA litigation represents only $0.043 \%$ of all civil litigation in which the federal government was a defendant (i.e., one out of roughly every 2,500 cases). Further, the last five years for

\footnotetext{
140 See supra Part IV.A.2.

141 See supra Fig. 3. The data comes from: Annual Statistical Reports, supra note 76.

142 The data comes from: Statistical Tables for the Federal Judiciary, U.S. CoURTS https://perma.cc/R9GU-W8HE (last visited Apr. 18, 2020).
} 
which we have NEPA litigation data (2009-2013) all experienced below average rates of NEPA litigation. The low percentage of NEPA litigation as a share of all federal litigation, when coupled with a downward trend in litigation hardly seems to support claims that NEPA litigation represents an undue burden for the federal government.

\begin{tabular}{|c|c|c|c|c|c|c|c|c|c|c|c|c|c|c|}
\hline & 2001 & 2002 & 2003 & 2004 & 2005 & 2006 & 2007 & 2008 & 2009 & 2010 & 2011 & 2012 & 2013 & Total \\
\hline $\begin{array}{c}\text { Fed. Dist. Ct. } \\
\text { Filings }\end{array}$ & 259,927 & 256,562 & 257,234 & 276,942 & 245,575 & 270,171 & 246,039 & 265,178 & 278,884 & 293,352 & 289,969 & 267,990 & 292,912 & $3,500,735$ \\
\hline $\begin{array}{c}\text { NEPA } \\
\text { Filings }\end{array}$ & 138 & 147 & 140 & 166 & 120 & 108 & 86 & 132 & 97 & 87 & 94 & 88 & 96 & 1,499 \\
\hline $\begin{array}{c}\text { NEPA \% of } \\
\text { all Filings }\end{array}$ & 0.053 & 0.057 & 0.054 & 0.060 & 0.049 & 0.040 & 0.035 & 0.050 & 0.035 & 0.030 & 0.032 & 0.033 & 0.033 & 0.043 \\
\hline
\end{tabular}

Table 4: Civil Litigation with Federal Defendants, 2001-2013

We also compared the number of NEPA lawsuits to the number of civil suits against the federal government that involve environmental or lands matters. ${ }^{143}$ As shown in Table 5, we found that NEPA represents $12.2 \%$ of all federal environmental or lands civil litigation against the United States. We also observed a general downward trend in the number of NEPA cases as a percent of environmental or lands litigation.

\begin{tabular}{|c|c|c|c|c|c|c|c|c|c|c|c|c|c|c|}
\hline & 2001 & 2002 & 2003 & 2004 & 2005 & 2006 & 2007 & 2008 & 2009 & 2010 & 2011 & 2012 & 2013 & Total \\
\hline $\begin{array}{c}\text { Matters_U.S. } \\
\text { as } \\
\text { Defendant }\end{array}$ & 1,807 & 790 & 947 & 978 & 714 & 871 & 767 & 920 & 741 & 942 & 726 & 696 & 1,436 & 12,335 \\
\hline $\begin{array}{c}\text { NEPA Case } \\
\text { Filings }\end{array}$ & 138 & 147 & 140 & 166 & 120 & 108 & 86 & 132 & 97 & 87 & 94 & 88 & 96 & 1,499 \\
\hline $\begin{array}{c}\text { NEPA Cases } \\
\text { as \% of Envtl. } \\
\text { Matters }\end{array}$ & 7.6 & 18.6 & 14.8 & 17.0 & 16.8 & 12.4 & 11.2 & 14.3 & 13.1 & 9.2 & 12.9 & 12.6 & 6.7 & 12.2 \\
\hline
\end{tabular}

Table 5: Environmental/Lands Litigation with Federal Defendants, 2001-2013

\section{Portion of NEPA Decisions Challenged in Court}

Based on our calculations of the number of NEPA documents produced ${ }^{144}$ and the number of NEPA lawsuits filed, ${ }^{145}$ we estimated that, over the thirteen year study period, only about $0.22 \%$ of NEPA

\footnotetext{
$143 \mathrm{Id}$.

144 See supra note 85 and accompanying text.

145 See supra note 138 and accompanying text.
} 
decisions (or roughly 1 in 450) were challenged in federal court. ${ }^{146}$ As previously noted, this should be viewed as a rough estimate due to challenges extrapolating the total number of NEPA documents from the number of EISs. ${ }^{147}$

The percentage of NEPA reviews challenged in court declined slightly over time, as shown in Figure 4, peaking in 2001 with $0.28 \%$ of NEPA reviews challenged in court and ending in 2013 with $0.24 \%$ of NEPA reviews challenged in court. The lowest rate of NEPA litigation occurred in 2007, when just $0.15 \%$ of NEPA decisions faced legal challenges. The low rate at which NEPA decisions are challenged, when coupled with an overall decline in the rate of challenges, does not appear to support claims that stakeholders are overly litigious or that NEPA litigation is unduly burdensome.

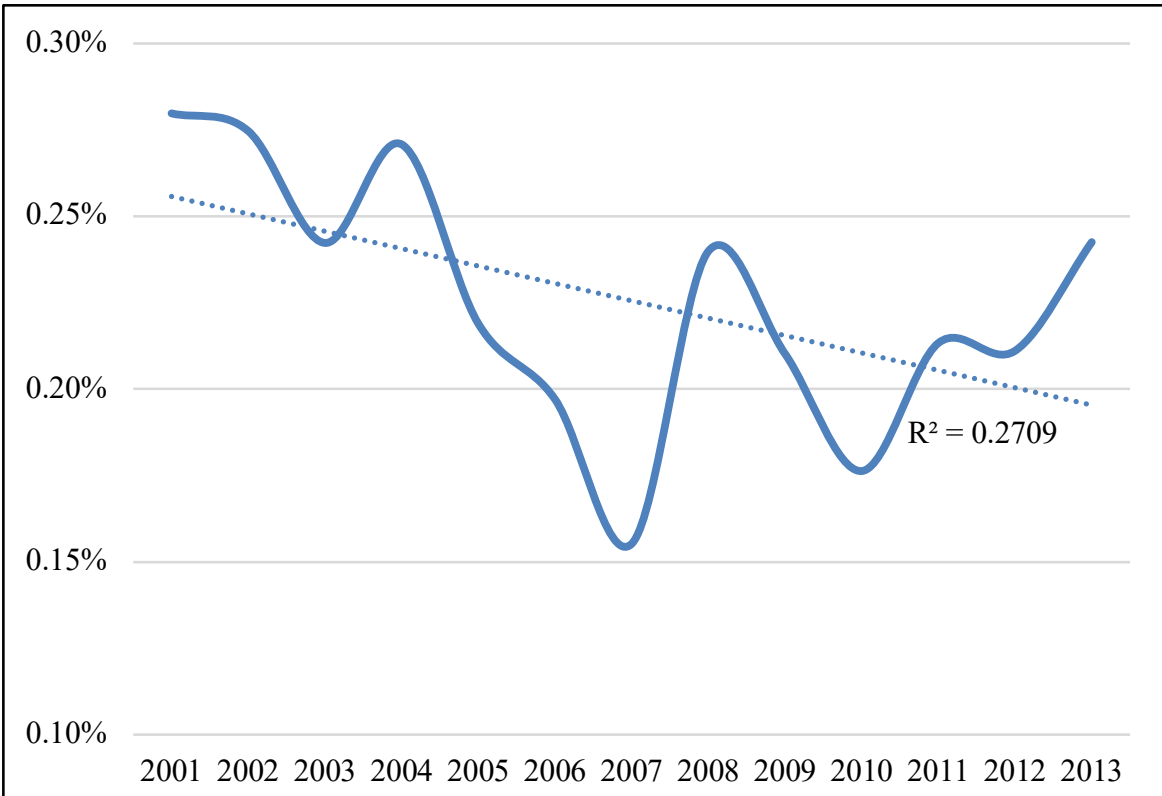

Figure 4: Estimated Percent of Final NEPA Decisions Challenged in Federal Court

\section{Type of NEPA Documents Challenged}

We found that $20.7 \%$ of all NEPA cases were resolved on justiciability or jurisdictional grounds. ${ }^{148}$ The CEQ's data does not

146 We calculated this by taking the number of NEPA lawsuits filed each year, as reported in the CEQ's NEPA Litigation Reports and dividing that by our calculated estimate of NEPA decisions completed. See supra Part IV.B.1.

147 See supra Part IV.A.1.

148 Calculated from the "Basis for disposition" data provided in NEPA LITIGATION REPORT, supra note 14 . The CEQ data labels all justiciability and jurisdictional ruling as 
delineate which type of NEPA documents were at issue in such rulings. Of the cases that survived jurisdictional and justiciability challenges, and that were not subject to settlement, $34.2 \%$ were resolved based on EIS adequacy; $26.6 \%$ were resolved based on EA adequacy; $6.4 \%$ were involved CE adequacy; and 6.7\% were resolved on the adequacy of a Supplemental EIS. ${ }^{149}$ Whether NEPA was required at all was the basis for determining $5.4 \%$ of all NEPA cases that were decided on the merits.

\section{Portion of Final EISs and Supplemental Final EISs Resulting in Court Rulings}

We estimated the number of final judgements on Final EISs and Supplemental EIS adequacy by comparing the number of Final EISs and Supplemental Final EISs produced by all federal agencies ${ }^{150}$ to the number of federal court decisions on the adequacy (or inadequacy) of an EIS or SEIS. 151

\begin{tabular}{|c|c|c|c|c|c|c|c|c|c|c|c|c|c|c|}
\hline & 2001 & 2002 & 2003 & 2004 & 2005 & 2006 & 2007 & 2008 & 2009 & $\begin{array}{c}201 \\
0\end{array}$ & 2011 & 2012 & 2013 & Total \\
\hline $\begin{array}{c}\text { Total } \\
\text { FEISs }\end{array}$ & 191 & 224 & 226 & 276 & 229 & 224 & 239 & 250 & 188 & 231 & 187 & 185 & 153 & 2803 \\
\hline $\begin{array}{c}\text { Resolved } \\
\text { on FEIS } \\
\text { adequacy }\end{array}$ & 38 & 47 & 30 & 25 & 38 & 55 & 64 & 36 & 41 & 22 & 47 & 0 & 9 & 452 \\
\hline $\begin{array}{c}\% \text { Resolved } \\
\text { on FEIS } \\
\text { adequacy }\end{array}$ & 19.9 & 21.0 & 13.3 & 9.1 & 16.6 & 24.6 & 26.8 & 14.4 & 21.8 & 9.5 & 25.1 & 0.0 & 5.9 & 16.1 \\
\hline $\begin{array}{l}\text { FEIS } \\
\text { Inade- } \\
\text { quate }\end{array}$ & & & & & 13 & 26 & 35 & 15 & 20 & 5 & 15 & 0 & 1 & 130 \\
\hline $\begin{array}{l}\% \text { FEISs } \\
\text { Inade- } \\
\text { quate }\end{array}$ & & & & & 5.7 & 11.6 & 14.6 & 6.0 & 10.6 & 2.2 & 8.0 & & 0.7 & $6.9 *$ \\
\hline
\end{tabular}

Table 6: NEPA Case Filings Challenging FEISs, 2001-2013

We found that overall $16.1 \%$ of Final EISs resulted in a federal court decision based on the adequacy or inadequacy of the EIS. ${ }^{152}$ While

simply "jurisdictional," but in examining the raw data we discovered such labels include cases that were decided on ripeness, mootness, and standing grounds, in addition to subject matter jurisdiction and personal jurisdiction.

149 EISs do not always bear consistent titles, and this analysis refers to all but the initial iteration of an EIS, whether draft or final, as a Supplemental EISs.

150 EIS production data comes from EPA EIS Database, supra note 36. The Database contains records of all EISs prepared by all federal agencies since 1987.

151 EIS litigation information comes from the "Basis for NEPA Disposition" section of the NEPA LITIGATION REPORT, supra note 14.

152 This percentage is calculated by dividing the 452 Final EIS litigation decisions by the 2,803 FEISs produced. See id. We note that $16.1 \%$ does not reflect the portion of FEISs challenged, as the CEQ data does not delineate the type of NEPA document in the initial filings data nor settlement data. Rather, 16.1\% reflects the number of FEISs that that were challenged and made it to a court ruling. The number of FEISs that were initially challenged but later withdrawn or settled before a court ruling could be higher. 
this number may appear high, it is important to remember that EISs are completed only for the most complicated and impactive $1 \%$ of all federal actions. ${ }^{153}$ Further, only $6.9 \%$ of Final EISs were held inadequate. ${ }^{154}$ These figures are displayed in Table 6.

Challenges to Supplemental Final EISs were more likely to be resolved based on document adequacy, with $28.9 \%$ of such documents resulting in a court decision based on its adequacy or inadequacy. ${ }^{155}$ Supplemental Final EISs also fared worse in court than Final EISs, but were still frequently upheld, with just $15.0 \%$ of Supplemental Final EISs being held inadequate. ${ }^{156}$ These figures are displayed in Table 7 .

That Supplemental Final EISs are challenged at a higher rate may indicate that errors and omissions in an EIS are uniquely difficult to correct, that a flawed analysis invites a higher level of ongoing scrutiny, or that projects that require supplemental NEPA analysis involve uniquely thorny problems.

\begin{tabular}{|c|c|c|c|c|c|c|c|c|c|c|c|c|c|c|}
\hline & 2001 & 2002 & 2003 & 2004 & 2005 & 2006 & 2007 & 2008 & 2009 & 2010 & 2011 & 2012 & 2013 & Total \\
\hline Total SEISs & 25 & 27 & 35 & 29 & 25 & 28 & 21 & 31 & 20 & 17 & 17 & 26 & 28 & 329 \\
\hline $\begin{array}{c}\text { Resolved on } \\
\text { SEIS } \\
\text { adequacy }\end{array}$ & 6 & 7 & 4 & 4 & 7 & 20 & 15 & 9 & 8 & 2 & 7 & 3 & 3 & 95 \\
\hline $\begin{array}{c}\text { \% Resolved } \\
\text { on SEIS } \\
\text { adequacy }\end{array}$ & 24.0 & 25.9 & 11.4 & 13.8 & 28.0 & 71.4 & 71.4 & 29.0 & 40.0 & 11.8 & 41.2 & 11.5 & 10.7 & 28.9 \\
\hline $\begin{array}{c}\text { SEIS } \\
\text { Inadequate }\end{array}$ & & & & 4 & 14 & 9 & 1 & 3 & 0 & 1 & 0 & 0 & 32 \\
\hline $\begin{array}{c}\text { \% SEISs } \\
\text { Inadequate }\end{array}$ & & & & 16.0 & 50.0 & 42.9 & 3.2 & 15.0 & 0.0 & 5.9 & & 0.0 & $15.0^{*}$ \\
\hline
\end{tabular}

* total based on 2005-2013

Table 7: NEPA Case Filings Challenging Supplemental FEISs, 2001-2013

\section{NEPA Litigation Burden by Agency}

In addition to calculating the portion of NEPA documents that were challenged on a governmentwide level, we also examined which agencies

153 See supra note 34 and accompanying text.

154 Unlike most other figures quoted in this paper, these results reflect only the period from 2005 through 2013 because data on the number of EISs deemed inadequate prior to 2005 was not available. This percentage is calculated taking the number of lawsuits labelled by the CEQ as having a court disposition in the plaintiff's favor based on the inadequacy of the EIS (130) and dividing that number by the number of FEISs produced $(1,886)$. NEPA LITIGATION REPORT, supra note 14.

155 This percentage is calculated by dividing the number of Supplemental Final EISbased litigation decisions involving SEIS adequacy (95) by the number of Supplemental Final EISs produced (329). Id.

156 These results reflect only the period from 2005 through 2013 because data on the number of EISs deemed inadequate was not available prior to 2005. The percentage is calculated taking the number of lawsuits labelled by the CEQ as having a court disposition in the plaintiff's favor based on the inadequacy of the Supplemental EIS (32) and dividing that number by the number of Supplemental Final EISs produced over the same time period (213). Id. 
were sued most frequently, as displayed in Table 8. Notably, NEPA case filings were below the governmentwide average for each of the last five years for which reportable data was available. 157 Three of the four primary land managers (Forest Service, Park Service, FWS) also experienced below average NEPA filings during three or more of the last five years of record, as did three of the four major agencies that focus on infrastructure development (DOE, Federal Highway Administration, FERC). 158

Over the 13-year dataset, the Forest Service was the most-sued agency for NEPA issues, facing 526 NEPA lawsuits between 2001 and 2013, averaging over 40 per year. In fact, the Forest Service has been sued under NEPA over twice as many times as any other federal agency and was responsible for $35 \%$ of all NEPA litigation governmentwide. ${ }^{159}$ The Forest Service also saw more NEPA lawsuits between 2001 and 2013 than the next four most-sued agencies combined, though the Forest Service was sued less than its 13 -year average in 4 of the last 5 years of record.

157 See infra Table 8.

158 See infra Table 8.

159 Calculated from the "Cases File" data provided in NEPA LITIGATION REPORT, supra note 14 . 


\begin{tabular}{|c|c|c|c|c|c|c|c|c|c|c|c|c|c|c|c|}
\hline & 2001 & 2002 & 2003 & 2004 & 2005 & 2006 & 2007 & 2008 & 2009 & 2010 & 2011 & 2012 & 2013 & $\begin{array}{l}\text { Total } \\
\text { Filed }\end{array}$ & $\begin{array}{c}\text { Annual } \\
\text { Mean }\end{array}$ \\
\hline Army Corps of Eng'rs & 7 & 13 & 12 & 13 & 8 & 25 & 1 & 15 & 5 & 6 & 3 & 10 & 8 & 126 & 9.7 \\
\hline Dep’t of Commerce & 8 & 10 & 6 & 15 & 3 & 4 & 2 & 8 & 12 & 5 & 8 & 8 & 7 & 96 & 7.4 \\
\hline Dep't of Defense & 4 & 3 & 2 & 3 & 2 & 1 & 1 & 3 & 2 & 3 & 0 & 1 & 0 & 25 & 1.9 \\
\hline Dep't of Energy & 2 & 4 & 1 & 4 & 3 & 0 & 1 & 6 & 4 & 1 & 2 & 0 & 0 & 28 & 2.2 \\
\hline $\begin{array}{l}\text { Bureau of Indian } \\
\text { Affairs \& Nat'l Indian } \\
\text { Gaming Comm'n }\end{array}$ & 3 & 3 & 2 & 0 & 2 & 1 & 2 & 3 & 0 & 1 & 0 & 1 & 1 & 19 & 1.5 \\
\hline Bureau of Land Mgmt. & 20 & 18 & 15 & 19 & 12 & 21 & 7 & 14 & 2 & 17 & 22 & 20 & 18 & 205 & 15.8 \\
\hline Bureau of Reclamation & 1 & 2 & 11 & 1 & 3 & 0 & 3 & 1 & 3 & 0 & 1 & 3 & 0 & 29 & 2.2 \\
\hline Fish \& Wildlife Serv. & 17 & 12 & 2 & 5 & 3 & 6 & 3 & 6 & 0 & 6 & 4 & 5 & 16 & 85 & 6.5 \\
\hline Nat'l Park Serv. & 7 & 4 & 1 & 4 & 4 & 0 & 2 & 6 & 0 & 2 & 4 & 4 & 3 & 41 & 3.2 \\
\hline $\begin{array}{l}\text { Dep't of the } \\
\text { Interior, } \\
\text { other agencies }\end{array}$ & 0 & 0 & 1 & 0 & 2 & 0 & 3 & 1 & 0 & 5 & 0 & 2 & 2 & 16 & 1.2 \\
\hline $\begin{array}{l}\text { Fed. Aviation } \\
\text { Admin. }\end{array}$ & 7 & 16 & 3 & 2 & 3 & 3 & 5 & 0 & 1 & 3 & 3 & 0 & 0 & 46 & 3.5 \\
\hline $\begin{array}{l}\text { Fed. Highway } \\
\text { Admin. }\end{array}$ & 3 & 10 & 6 & 11 & 5 & 7 & 4 & 9 & 12 & 10 & 14 & 4 & 1 & 96 & 7.4 \\
\hline $\begin{array}{l}\text { Fed. Transit } \\
\text { Admin. }\end{array}$ & 13 & 7 & 2 & 0 & 2 & 1 & 2 & 1 & 1 & 2 & 2 & 3 & 3 & 39 & 3.0 \\
\hline $\begin{array}{l}\text { Dep't of Transp., } \\
\text { other agency }\end{array}$ & 0 & 1 & 2 & 0 & 2 & 0 & 0 & 0 & 0 & 0 & 1 & 0 & 1 & 7 & 0.5 \\
\hline Envtl. Prot. Agency & 4 & 1 & 0 & 6 & 2 & 2 & 2 & 1 & 1 & 1 & 1 & 0 & 0 & 21 & 1.6 \\
\hline $\begin{array}{l}\text { Federal Energy } \\
\text { Regulatory Comm'n }\end{array}$ & 0 & 0 & 0 & 2 & 4 & 2 & 2 & 3 & 2 & 0 & 0 & 0 & 1 & 16 & 1.2 \\
\hline $\begin{array}{c}\text { Nuclear Regulatory } \\
\text { Comm'n }\end{array}$ & 0 & 0 & 1 & 2 & 0 & 3 & 0 & 3 & 4 & * & 1 & 0 & 0 & 14 & 1.1 \\
\hline $\begin{array}{c}\text { Animal \& Plant } \\
\text { Health Inspection } \\
\text { Serv. }\end{array}$ & 2 & 0 & 3 & 3 & 3 & 2 & 1 & 3 & * & 4 & 2 & 1 & 2 & 26 & 2.0 \\
\hline Forest Serv. & 40 & 40 & 66 & 76 & 50 & 30 & 40 & 46 & 42 & 18 & 25 & 25 & 28 & 526 & 40.5 \\
\hline $\begin{array}{l}\text { Dep't of Agric., } \\
\text { other agency }\end{array}$ & & & & & & & & & 1 & & & & 1 & 2 & 0.2 \\
\hline Other & 0 & 3 & 4 & 0 & 7 & 0 & 5 & 3 & 5 & 3 & 1 & 1 & 4 & 36 & 2.8 \\
\hline All Agencies & 138 & 147 & 140 & 166 & 120 & 108 & 86 & 132 & 97 & 87 & 94 & 88 & 96 & 1,499 & 115.3 \\
\hline
\end{tabular}

Table 8: NEPA Case Filings in Federal Court, 2001-2013

The high proportion of NEPA lawsuits against the Forest Service (35\% of all NEPA lawsuits) may be partly explained by the large share of EISs produced by the Forest Service, which amounts to $26 \%$ of all Final and Supplemental Final EISs governmentwide. ${ }^{160}$ Clearly, however, the Forest Service's share of NEPA litigation is greater than 
its share of EIS production. In fact, we estimate that Forest Service NEPA decisions were challenged at almost three times the governmentwide rate, with $0.6 \%$ of all Forest Service NEPA reviews challenged, ${ }^{161}$ while only approximately $0.2 \%$ of governmentwide NEPA decisions were challenged. ${ }^{162}$ Moreover, other recent NEPA litigation scholarship found the Forest Service's governmentwide share of EISspecific litigation was 1.4 times its share of EISs produced, meaning that Forest Service EISs were challenged in court approximately $40 \%$ more often than anticipated based on the number of EISs they completed. ${ }^{163}$ Perhaps one factor behind the Forest Service's high litigation rates is the fact that the Forest Service prepares a higher percentage of EISs and fewer CEs than its sister agencies, ${ }^{164}$ which may indicate that its projects are anticipated to have a higher level of impact and therefore spark more intense public scrutiny.

By comparison, between 2001 and 2013, the BLM was a defendant in 205 NEPA suits, averaging 15.8 per year and making up $13.7 \%$ of all NEPA lawsuits governmentwide. 165 The Army Corps was the lead agency in 126 NEPA lawsuits, averaging 9.7 per year and making up 8.4\% of NEPA lawsuits governmentwide. 166 The Federal Highway Administration and the Department of Commerce were the lead agencies in 96 lawsuits each, averaging 7.4 per year and each making up $6.4 \%$ of NEPA lawsuits. 167 The FWS averaged 6.5 NEPA lawsuits per year, for a total of 85 NEPA lawsuits between 2001 and 2013, making up $5.7 \%$ of governmentwide NEPA lawsuits. ${ }^{168}$ The Federal Aviation Administration was the lead agency in 46 NEPA lawsuits, averaging 3.5 NEPA lawsuits per year, and making up 3.1\% of NEPA lawsuits governmentwide. 169 The Park Service was the lead agency in 41 NEPA lawsuits, averaging 3.2 lawsuits per year, and making up $2.7 \%$ of governmentwide NEPA lawsuits per year. ${ }^{170}$

161 Our calculation uses the number of cases filed against the Forest Service (526), divided by the estimated number of Forest Service NEPA decisions $(84,950)$, which is based on the EPA's data on the number of Draft, Final, and Supplemental Final EISs produced by the Forest Service (1699) and the GAO's reporting that $2 \%$ of Forest Service NEPA reviews are Final EISs. U.S. GOV'T ACCOUNTABILITY OFF., supra note 9, at 8.

162 See supra Part IV.B.3 and text discussing NEPA decisions challenged in court.

163 Adelman \& Glicksman, supra note 12, at 30 tbl.1. Note that Adelman \& Glicksman compare EISs produced to EIS lawsuits, whereas our comparison using CEQ data examines EISs produced to general NEPA lawsuits, not specifically lawsuits over EISs.

164 See supra note 37 and accompanying text.

165 Calculated from the "Cases Filed" data provided in NEPA LITIGATION REPORT, supra note 14 .

166 Id.

167 Id.

$168 \mathrm{Id}$.

$169 \mathrm{Id}$.

170 Id. 
The BLM produced $8.3 \%$ of Final and Supplemental Final EISs governmentwide, ${ }^{171}$ and recent NEPA scholarship found the BLM's governmentwide share of EIS lawsuits was roughly equal to its share of EISs produced. ${ }^{172}$ We estimate that the BLM's NEPA decisions (EISs, EAs, and CEs) were challenged $0.4 \%$ of the time, ${ }^{173}$ which is the same rate as the governmentwide average. The NPS produced 5.9\% of Final and Supplemental Final EISs governmentwide between 2001 and 2013. ${ }^{174}$ Based on our estimate of total NPS NEPA document production and the 41 NEPA lawsuits filed against the NPS, we estimate that only $0.1 \%$ of all NPS NEPA decisions were challenged in court. ${ }^{175}$ Finally, the FWS produced $2.6 \%$ of all Final and Supplemental Final EISs governmentwide during that same time period. ${ }^{176}$ Based on an estimated 16,300 NEPA decisions over the analysis period and 85 NEPA lawsuits filed, we calculate that $0.5 \%$ of all of the Service's NEPA decisions were challenged in court, ${ }^{177}$ more than twice the governmentwide average of $0.2 \% .{ }^{178}$ However, because the overall number of NEPA lawsuits is low for the FWS, the agency's NEPA litigation burden remained comparatively light.

171 Our calculation reflects the number of Final and Supplemental Final EISs prepared by the BLM (259) divided by the number of Final and Supplemental Final EISs prepared by all agencies $(3,132)$. EPA EIS Database, supra note 36.

172 Adelman \& Glicksman, supra note 12 , at 30 tbl.1.

173 Our calculation is the number of cases filed against the BLM (205), divided by the estimated number of the BLM's NEPA decisions $(53,600)$, which is based on the EPA's data on the number of Draft, Final, and Supplemental Final EISs produced by the BLM (536) and the GAO's estimate 1\% of NEPA reviews governmentwide are Final EISs, as no BLM-specific estimate was available. U.S. Gov'T ACCOUNTABILITY OFFICE, supra note 9, at 8.

174 Our calculation reflects the number of Final and Supplemental Final EISs prepared by the NPS (185) divided by the number of Final and Supplemental Final EISs prepared by all agencies $(3,132)$. EPA EIS Database, supra note 36.

175 Our calculation of the number of the NPS's NEPA decisions is based on the EPA's data on the number of Final and Supplemental Final EISs produced and the GAO's estimate 1\% of NEPA reviews governmentwide are Final EISs, as no NPS-specific estimate was available. U.S. GOv'T ACCOUNTABILITY OFFICE, supra note 9, at 8.

176 Our calculation reflects the number of Final and Supplemental Final EISs prepared by the FWS (80) divided by the number of Final and Supplemental Final EISs prepared by all agencies (3,132). EPA EIS Database, supra note 36.

177 Our calculation of the number of FWS NEPA decisions is based on the EPA's data on the number of Draft, Final, and Supplemental Final EISs produced by the FWS between 2001 and 2013 (173) and the GAO's estimate 1\% of NEPA reviews governmentwide are Final EISs, as no FWS-specific estimate was available. U.S. GOV'T ACCOUNTABILITY OFFICE, supra note 9, at 8. As explained in Part IV.A.1, we reviewed BLM NEPA filings from 2005 through 2018 and found that just $0.43 \%$ of the BLM's NEPA reviews involved an EIS. Extrapolating from these figures, we estimate that just $0.2 \%$ of all BLM NEPA decisions are challenged in court. We chose not to extrapolate from these figures in the body of this report because we do not know if the figures obtained from the BLM's ePlanning website are complete or indicative of averages over the entire study period. This highlights the importance of developing better mechanisms to track all NEPA decisions.

178 See supra Part IV.B.3 and text discussing NEPA decisions challenged in court. 
It is also worth noting other NEPA litigation scholarship has found that agencies in charge of a significant amount of infrastructure work faced a lower share of EIS litigation than anticipated based on the number of EISs they produced. For example, the Federal Highway Administration's share of EIS litigation was just $30 \%$ of what was anticipated based on the number of EISs it produced. ${ }^{179}$ Similarly, the Army Corps' share of EIS litigation was half of that anticipated based on the number of EISs they produced. ${ }^{180}$ It is not clear whether these differences reflect differences in the level of scrutiny for particular projects or differences in the way agencies approach NEPA compliance.

\section{NEPA Litigation Outcomes}

This section looks at: 1 ) the rate at which the federal government wins, loses, and settles NEPA litigation; 2) the success rates of different types of NEPA documents in court rulings; 3) how litigation outcomes vary across agencies; and 4) how NEPA litigation success rates compare to outcomes in other federal environmental litigation in which the federal government is a defendant. We found that some agencies fare better than others in NEPA litigation, but overall, federal agencies prevail in NEPA litigation at rates comparable to other environmental matters in which the agencies are defendants. We also found that governmentwide, agency success rates in NEPA litigation are improving over time.

\section{NEPA Litigation "Win" Rates}

We examined the CEQ's published NEPA Litigation Reports ${ }^{181}$ to calculate governmentwide and agency-level outcomes in three categories: "win,"182 "loss,"183 and "neutral."184 Between 2001 and 2013,

179 Adelman \& Glicksman, supra note 12 , at 30 tbl.1.

180 Id.

181 See NEPA Litigation REPORT, supra note 14. The CEQ's "Case Dispositions" data provides information on the type of relief granted.

182 "Wins" include rulings labelled by the CEQ as "judgment for defendant" and "dismissal without settlement." This includes cases where the court found the agency had met its burden; cases that were decided favorably for the agency on justiciability, jurisdictional, or procedural grounds; and when the plaintiffs withdrew their claim prior to a decision on the merits or when the plaintiff agreed to a voluntary dismissal. We count as a "win" any decision that resolved the matter in a way that did not call the agency's NEPA compliance efforts into question or require further action on the part of the lead agency even if the decision was not on the merits.

183 Federal government "losses" include rulings labeled by the CEQ as "remand" and "permanent injunction." These rulings include when the federal government lost on the merits of a NEPA claim; and when the government withdrew the project, plan, or decision prior to a judicial decision on the merits, but where no settlement was listed. We treated voluntary withdrawal of a project by an agency as a "loss" because the proposed action could not proceed without further NEPA action on the part of the lead agency. This may slightly overstate government "losses" because a project proposed by a non-federal actor 
the federal government "won" $63.3 \%$ of final outcomes in NEPA cases, "lost" $18.6 \%$ of the cases, and had neutral outcomes in $18.1 \%$ of the cases. ${ }^{185}$ Over the 13-year period studied, the federal government's win rate in NEPA litigation increased overall (with some variation), and the government prevailed at above average rates in each of the past five years of record. ${ }^{186}$ The federal government's loss rate was below the 13year average in each of the past five years of record, and the rate of neutral outcomes also declined during each of the past five years. ${ }^{187}$

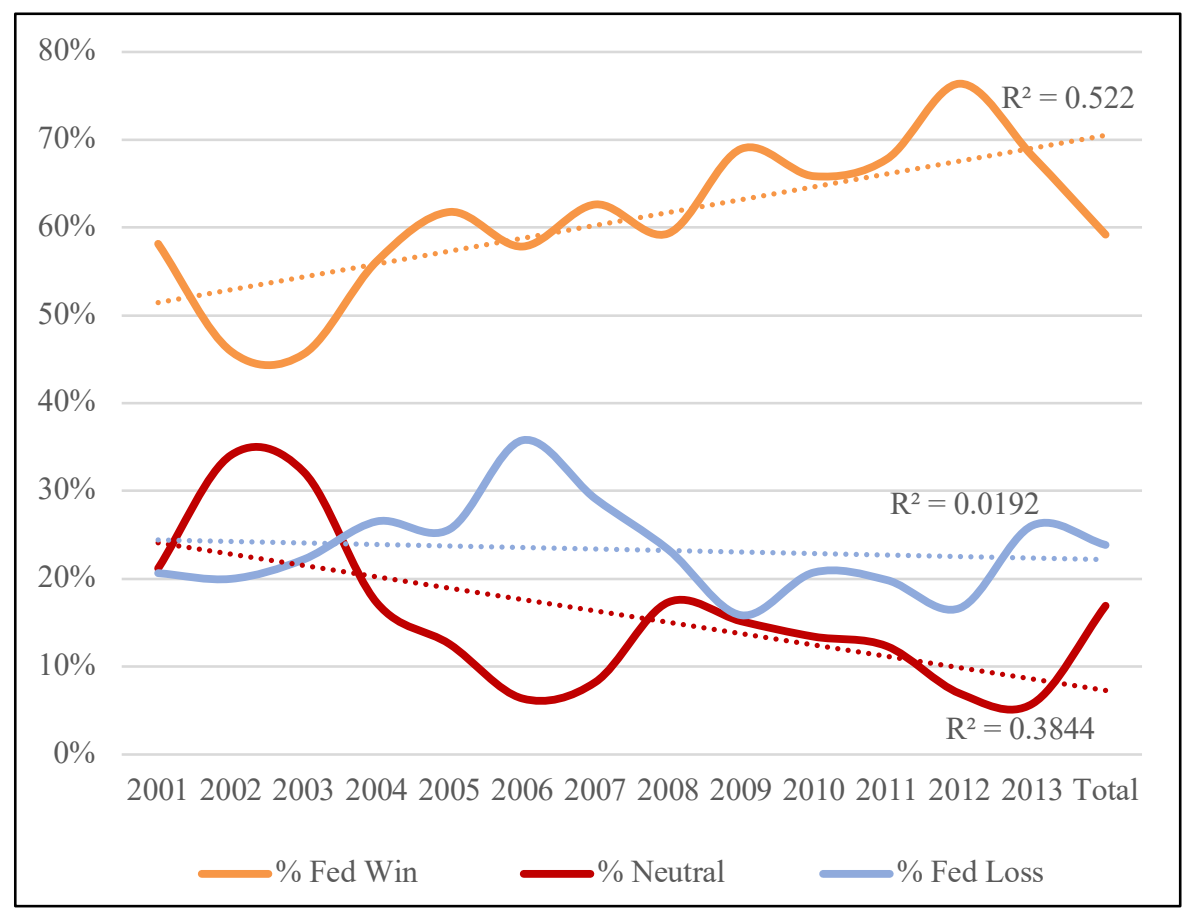

Figure 5: NEPA Litigation Outcomes 2001-2013

As shown in Table 9, the CEQ's reports also include data on the number of Temporary Restraining Orders (TRO) and Preliminary Injunctions ordered by a reviewing court. ${ }^{188}$ Such temporary relief is

could be withdrawn by that actor for reasons that have nothing to do with NEPA adequacy.

184 Neutral outcomes include dismissals with settlement and outcomes labeled as "other" by the CEQ. Temporary relief was excluded from these calculations as such temporary relief does not reflect a final outcome.

185 These numbers are calculated by dividing the number of winning, losing, and neutral outcomes by the total number of NEPA cases disposed of in that year.

186 See infra Figure 5 and Table 9.

187 See infra Figure 5 and Table 9.

188 The CEQ's reports do not include data on the number of motions for a TRO or Preliminary Injunction. We could not determine the rate at which preliminary relief was granted against the government without such information. 
important to note because it may delay implementation of agency actions. Between 2001 and 2013, plaintiffs in 128 NEPA lawsuits obtained temporary relief - either a TRO or a preliminary injunction. 189 We do not, however, consider these to be "losses" for the government as they merely maintain the status quo while litigation remains pending, and temporary relief does not indicate that the plaintiffs eventually prevailed on the merits.

\begin{tabular}{|c|c|c|c|c|c|c|c|c|c|c|c|c|c|c|c|}
\hline & & 2001 & 2002 & 2003 & 2004 & 2005 & 2006 & 2007 & 2008 & 2009 & 2010 & 2011 & 2012 & 2013 & Total \\
\hline \multirow{2}{*}{$\sum_{E}$} & Judgement for U.S. & 66 & 49 & 49 & 50 & 94 & 84 & 87 & 77 & 76 & 46 & 79 & 46 & 29 & 832 \\
\hline & $\begin{array}{c}\text { Dismissal w/o } \\
\text { Settlement }\end{array}$ & 41 & 52 & 29 & 41 & 24 & 34 & 27 & 12 & 24 & 8 & 20 & 9 & 18 & 339 \\
\hline \multirow{2}{*}{ 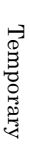 } & $\begin{array}{c}\text { Temp. Restraining } \\
\text { Order }\end{array}$ & 5 & 2 & 4 & 4 & 1 & 1 & 2 & 0 & 0 & 0 & 0 & 2 & 2 & 23 \\
\hline & Preliminary Injunction & 6 & 8 & 11 & 15 & 18 & 8 & 10 & 6 & 2 & 5 & 5 & 6 & 5 & 105 \\
\hline \multirow{2}{*}{$\begin{array}{l}5 \\
\\
0 \\
0 \\
0\end{array}$} & Permanent Injunction & 9 & 19 & 7 & 7 & 7 & 16 & 18 & 10 & 15 & 4 & 3 & 0 & 3 & 118 \\
\hline & Remand & 18 & 15 & 16 & 17 & 23 & 48 & 23 & 19 & 6 & 8 & 21 & 4 & 8 & 226 \\
\hline \multirow{3}{*}{ 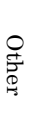 } & Dismissal w/ Settlement & 24 & 22 & 22 & 28 & 24 & 13 & 15 & 26 & 22 & 11 & 18 & 5 & 4 & 234 \\
\hline & Other & 15 & 53 & 33 & 0 & & & & & & & & & & 101 \\
\hline & Pending & 135 & 168 & 205 & 251 & 24 & 195 & 168 & 233 & 271 & & & & & \\
\hline
\end{tabular}

Table 9: NEPA Litigation Outcomes, 2001-2013

\section{Success Rates Based on Type of NEPA Review}

We used the CEQ's published data to analyze the types of NEPA documents most often at issue in judicial decisions ${ }^{190}$ and the government's success rates for each type of NEPA document. ${ }^{191}$ Unlike most of this Article, this section of our analysis is limited to 2005 through 2013 because earlier data does not include information on all possible litigation outcomes. As shown in Table 10, when NEPA cases were decided on ripeness, mootness, standing grounds, subject matter jurisdiction, or personal jurisdiction, the federal government won $86.1 \%$ of the time. ${ }^{192}$ The federal government won $69.8 \%$ of the time when the question involved whether NEPA was required. ${ }^{193}$ When the adequacy of a $\mathrm{CE}$ was the basis for a court ruling, the federal government won $68.2 \%$

189 See infra Table 9.

190 See supra Part IV.B.5 (discussing types of NEPA documents most often at issue).

191 Calculated using the "Basis for NEPA Dispositions" data provided in NEPA LITIGATION REPORT, supra note 14.

192 See also Adelman \& Glicksman, supra note 12, at 34-35 (finding that constitutional standing was the single most frequently litigated issue, but defendants were rarely successful in bringing such a defense).

193 See infra Table 10. 
of the time. ${ }^{194}$ The federal government won $62.3 \%$ of the time when EA adequacy was the basis for case disposition. When the court ruled on EIS adequacy, the federal government won $58.3 \%$ of the time. ${ }^{195}$ The federal government was the least successful when Supplemental EIS adequacy was challenged, winning those challenges $52.2 \%$ of the time. ${ }^{196}$

Because we were working with aggregated data, we were unable to determine whether these differences were statistically significant. We note, however, that Adelman and Glicksman found an absence in statistically significant variation in success rates for different types of NEPA claims. ${ }^{197}$

194 Calculated from the "Basis for NEPA Dispositions" data provided from 2005 to 2013 in NEPA LITIGATION REPORT, supra note 14.

195 Calculated from the "Basis for NEPA Dispositions" data provided from 2005 to 2013 in NEPA LITIGATION REPORT, supra note 14 . This means that $41.7 \%$ of EISs that were subject to a court ruling on the merits were held inadequate. However, as a portion of final EISs produced, only $6.9 \%$ of final EISs were ruled inadequate. See infra Part IV.B.5 (discussing the portion of final EISs resulting in court rulings).

196 Calculated from the "Basis for NEPA Dispositions" data provided from 2005 to 2013 in NEPA LITIGATION REPORT, supra note 14. However, as a portion of Supplemental EISs produced, only $15 \%$ of SEISs were ruled inadequate. See infra Part IV.B.5 (discussing the portion of supplemental final EISs resulting in court rulings).

197 Adelman \& Glicksman, supra note 12, at 34. 


\begin{tabular}{|c|c|c|c|c|c|c|c|c|c|c|}
\hline & 2005 & 2006 & 2007 & 2008 & 2009 & 2010 & 2011 & 2012 & 2013 & Total \\
\hline Jurisdictional & 27 & 27 & 15 & 28 & 0 & 12 & 22 & 13 & 7 & 151 \\
\hline Agency prevailed & 25 & 14 & 12 & 27 & 0 & 12 & 20 & 13 & 7 & 130 \\
\hline Plaintiff prevailed & 2 & 13 & 3 & 1 & 0 & 0 & 2 & 0 & 0 & 21 \\
\hline$\%$ Agency Win & 92.6 & 51.9 & 80.0 & 96.4 & & 100.0 & 90.9 & 100.0 & 100.0 & 86.1 \\
\hline NEPA required? & 13 & 4 & 14 & 3 & 4 & 3 & 8 & 0 & 4 & 53 \\
\hline NEPA Not Required & 9 & 4 & 10 & 3 & 2 & 1 & 4 & 0 & 4 & 37 \\
\hline NEPA Required & 4 & 0 & 4 & 0 & 2 & 2 & 4 & 0 & 0 & 16 \\
\hline$\%$ Agency Win & 69.2 & 100.0 & 71.4 & 100.0 & 50.0 & 33.3 & 50.0 & -- & 100.0 & 69.8 \\
\hline CE Adequacy & 12 & 13 & 13 & 8 & 5 & 5 & 10 & 0 & 0 & 66 \\
\hline CE Adequate & 10 & 9 & 7 & 5 & 5 & 4 & 5 & 0 & 0 & 45 \\
\hline CE Inadequate & 2 & 4 & 6 & 3 & 0 & 1 & 5 & 0 & 0 & 21 \\
\hline$\%$ Agency Win & 83.3 & 69.2 & 53.8 & 62.5 & 100.0 & 80.0 & 50.0 & & & 68.2 \\
\hline EA Adequacy & 44 & 50 & 29 & 23 & 28 & 16 & 29 & 5 & 7 & 231 \\
\hline EA Adequate & 24 & 27 & 14 & 14 & 23 & 11 & 24 & 2 & 5 & 144 \\
\hline EA Inadequate & 20 & 23 & 15 & 9 & 5 & 5 & 5 & 3 & 2 & 87 \\
\hline$\%$ Agency Win & 54.5 & 54.0 & 48.3 & 60.9 & 82.1 & 68.8 & 82.8 & 40.0 & 71.4 & 62.3 \\
\hline EIS Adequacy & 38 & 55 & 64 & 36 & 41 & 22 & 47 & 0 & 9 & 312 \\
\hline EIS Adequate & 25 & 29 & 29 & 21 & 21 & 17 & 32 & 0 & 8 & 182 \\
\hline EIS Inadequate & 13 & 26 & 35 & 15 & 20 & 5 & 15 & 0 & 1 & 130 \\
\hline$\%$ Agency Win & 65.8 & 52.7 & 45.3 & 58.3 & 51.2 & 77.3 & 68.1 & -- & 88.9 & 58.3 \\
\hline SEIS Adequacy & 7 & 18 & 15 & 9 & 6 & 2 & 7 & 0 & 3 & 67 \\
\hline SEIS Adequate & & & & & & 1 & 1 & 0 & 3 & 5 \\
\hline SEIS Not Needed & 3 & 4 & 6 & 8 & 3 & 1 & 5 & 0 & 0 & 30 \\
\hline SEIS Needed & 4 & 14 & 9 & 1 & 3 & 0 & 1 & 0 & 0 & 32 \\
\hline$\%$ Agency Win & 42.9 & 22.2 & 40.0 & 88.9 & 50.0 & 100.0 & 85.7 & -- & 100.0 & 52.2 \\
\hline Total & 141 & 167 & 150 & 107 & 84 & 60 & 123 & 18 & 30 & 880 \\
\hline Total Agency Wins & 96 & 87 & 78 & 78 & 54 & 47 & 91 & 15 & 27 & 573 \\
\hline Total \% Agency Wins & 68.1 & 52.1 & 52.0 & 72.9 & 64.3 & 78.3 & 74.0 & 83.3 & 90.0 & 65.1 \\
\hline
\end{tabular}

Table 10: NEPA Litigation Outcome Summary, 2005-2013

\section{NEPA Outcomes by Lead Agency}

In addition to calculating NEPA litigation outcomes on a governmentwide basis, we also examined the success rate of the eight agencies who are sued the most frequently over NEPA decisions. This information is displayed in Table 11. Because the CEQ's published 
summary reports on NEPA litigation ${ }^{198}$ lacked agency-level win-losssettle data, we obtained raw data from the CEQ to make these calculations, ${ }^{199}$ relying wherever possible on the CEQ's labels of the type of relief granted and the basis for disposition (e.g., justiciability, adequacy of the NEPA decision, or other). 200

Overall, the eight most-sued agencies won slightly less often and had fewer neutral outcomes compared to the governmentwide averages. The most-sued agencies won $60.2 \%$ of NEPA litigation, lost $23.6 \%$ of NEPA litigation, and had neutral outcomes $10.3 \%$ of NEPA litigation. In comparison, the federal government overall won $63.3 \%$ of their cases, lost $18.6 \%$ of their cases, and had neutral outcomes $18.1 \%$ of the time.201

198 NEPA LITIGATION REPORT, supra note 14.

199 We contacted the CEQ and requested copies of the raw data that CEQ utilized to prepare the summary statistics that are posted on the CEQ website. The CEQ graciously shared this data, which is on file with the authors. For this agency-level breakdown, we omitted 2004 and 2005 data from our analysis because the CEQ's raw data did not distinguish between sub-agencies within large departments (e.g., Department of Interior litigation did not distinguish between cases involving the BLM, the FWS, or the NPS). We chose not to make our own determinations of the lead agency by reexamining each case in court docket databases because cases often involved multiple defendant agencies and we could not ensure our labeling methods would be consistent with those used by the CEQ for the other nine years of data.

200 Although we relied on the CEQ's labeling to the maximum extent possible, some of the CEQ's agency-level raw data labels were unclear, forcing us to make occasional judgement calls. For example, the CEQ's raw data occasionally labeled outcomes as "mixed rulings," rather than as one of the outcome categories that would allow us to clearly find a win, loss, or neutral. In these situations, we did not code a win/loss/neutral label, but instead counted those cases as unlabeled "others" in the total number of rulings for that year. On average, 5.4\% of rulings were "other," while the annual average ranges from $0.8 \%$ to $7.9 \%$ of rulings. Due to the inclusion of these unlabeled other outcomes, some win /loss/neutral percentages for individual agencies total to less than $100 \%$. It was also occasionally unclear from the CEQ's labeling whether remands at the appellate level were favorable or unfavorable for the government. In such instances, we found the court opinions, identified the district court ruling, and determined whether the appellate outcome for the NEPA claim was favorable or unfavorable to the government.

201 The total number of dispositions shown in Table $11(1,850)$ is greater than the total number of dispositions in Table $8(1,499)$ because multiple rulings may have occurred in the same case. The government, for example, may have lost a motion to dismiss on jurisdictional grounds only to later prevail on NEPA adequacy. 


\begin{tabular}{|c|c|c|c|c|}
\hline Agency & Final Rulings & \% Lost & \% Neutral & \% Win \\
\hline $\begin{array}{c}\text { Army Corps of Engineers } \\
\text { NOAA \& National Marine Fisheries } \\
\text { Service }\end{array}$ & 131 & 24.4 & 9.2 & 65.6 \\
\hline BLM & 114 & 20.2 & 7.9 & 54.0 \\
\hline FWS & 175 & 27.4 & 11.4 & 71.3 \\
\hline NPS & 80 & 16.3 & 10.0 & 51.2 \\
\hline $\begin{array}{c}\text { Fed. Aviation } \\
\text { Administration }\end{array}$ & 41 & 31.7 & 14.6 & 73.7 \\
\hline $\begin{array}{c}\text { Fed. Highway } \\
\text { Administration }\end{array}$ & 104 & 10.5 & 10.5 & 70.2 \\
\hline Forest Service & 520 & 26.3 & 10.8 & 5.7 \\
\hline $\begin{array}{c}\text { Total for Eight } \\
\text { Most-Sued Agencies }\end{array}$ & 1,222 & 23.6 & 10.3 & \multicolumn{2}{|c|}{60.2} \\
\hline All Federal Agencies & 1,850 & 18.6 & 18.1 & \\
\hline
\end{tabular}

Table 11: NEPA Outcomes by Lead Agency

Of the most-sued agencies, the Federal Aviation Administration was the agency most likely to prevail in litigation, with $73.7 \%$ of its NEPA litigation resulting in a win, $10.5 \%$ in a loss, and $10.5 \%$ in a neutral outcome. The FWS also fared well, with $71.3 \%$ of its NEPA litigation resulting in a win, $16.3 \%$ in a loss, and $10 \%$ in a neutral outcome. The Federal Highway Administration was close behind, winning $70.2 \%$ of its NEPA litigation, losing $15.4 \%$, and having a neutral outcome in $8.7 \%$ of cases.

The Army Corps and NOAA/National Marine Fisheries Service won $65.6 \%$ and $64 \%$ of NEPA litigation, respectively. The BLM and the Forest Service won their NEPA litigation $56 \%$ and $55 \%$ of the time, respectively, and lost $27.4 \%$ and $26.3 \%$ of the time, respectively. ${ }^{202}$ The NPS was the least successful agency-winning the least, losing the most, and having more neutral outcomes than any of the top eight mostsued agencies. The NPS won its NEPA litigation just $51.2 \%$ of cases, lost $31.7 \%$, and had neutral outcomes $14.6 \%$ of the time.

Our agency-level success findings based on the CEQ's reporting differs from that of other recent NEPA litigation scholarship, which found that the rate at which plaintiffs prevailed was largely uniform across agencies and types of claims raised, and any variation observed was more generally correlated with the presidential administration in

202 For comparison to the CEQ's data, an article examining Forest Service NEPA litigation with published opinions issued between 1970 and 2001 found that the "Forest Service won $60 \%$, lost $20 \%$, and had other judgements in $20 \%$ " of NEPA cases brought against them. Broussard \& Whitaker, supra note 43, at 137. That article also examined the type of NEPA document at issue in Forest Service NEPA litigation and found that, at the district court level, $55 \%$ of decisions involved cases where plaintiffs argued that an EA or EIS should have been prepared, and $36 \%$ of cases involved an inadequate EA or EIS. Id. at 138; see also Miner et al., supra note 43, at 116, 122 (finding that the Forest Service won $51.5 \%$ of land management litigation between 1989 and 2008, and won NEPA claims $69.3 \%$ of the time). 
charge and the political affiliation of the president who appointed the judges making the decisions. ${ }^{203}$

\section{NEPA Litigation Outcomes Compared to Other Federal Cases}

To put NEPA litigation into context, we examined data published by the Office of the United States Attorneys.204 We analyzed the outcomes of all civil litigation in which the federal government was a party, as well as civil litigation over environmental or lands issues where the federal government was a defendant. ${ }^{205}$ Unfortunately, coding differences between the CEQ's NEPA litigation reporting and the Office of U.S. Attorneys' general civil litigation reporting preclude a direct comparison between the two data sets.

As displayed in Table 12, data from the Office of U.S. Attorneys labels $30.7 \%$ of civil litigation cases handled by the U.S. Attorney between 2001 and 2013 as an "other" outcome-i.e. neither a win, loss, settlement, or dismissal. This results in a paradoxical outcome wherein the federal government wins less and loses less in civil litigation over all matters than it does in NEPA litigation, while settlement rates are largely equal to neutral outcomes in NEPA litigation. Including dismissals, the federal government won ${ }^{206}$ just $41.4 \%$ of all civil litigation between 2001 and $2013^{207}$ (whereas the government won $63.3 \%$ of NEPA litigation ${ }^{208}$ ). However, the federal government also only lost $10.8 \%$ of civil cases (whereas it lost $18.6 \%$ of NEPA cases ${ }^{209}$ ). The federal government settled $17.2 \%$ of its civil cases during that same time period (while it had neutral outcomes in $18.1 \%$ of NEPA cases ${ }^{210}$ ).

\footnotetext{
203 Adelman \& Glicksman, supra note 12, at 25.

204 Annual Statistical Reports, supra note 76.

205 We limited our analysis to cases where the federal government was a defendant because NEPA litigation is unlikely to be initiated by a federal agency. Focusing on other cases where federal agencies are a defendant therefore ensures that we are comparing like cases.

206 Wins include judgements for the government and dismissals.

207 See infra Table 12.

208 See supra Table 11.

209 See supra Table 11.

210 See supra Table 11.
} 


\begin{tabular}{|c|c|c|c|c|c|c|c|c|c|c|c|c|c|c|}
\hline & 2001 & 2002 & 2003 & 2004 & 2005 & 2006 & 2007 & 2008 & 2009 & 2010 & 2011 & 2012 & 2013 & Avg. \\
\hline For U.S. & 29.6 & 30.7 & 31.7 & 30.2 & 33.6 & 33.4 & 30.8 & 29.4 & 30.6 & 27.6 & 25.3 & 28.5 & 26.3 & 29.7 \\
\hline Settled & 23.1 & 21.6 & 22.8 & 21.2 & 19.6 & 19.9 & 16.2 & 14.5 & 14.4 & 14.7 & 13.9 & 13.2 & 10.3 & 17.2 \\
\hline $\begin{array}{c}\text { Against } \\
\text { U.S. }\end{array}$ & 9.9 & 9.4 & 9.2 & 10.2 & 11.0 & 10.3 & 10.3 & 16.1 & 12.2 & 9.3 & 9.3 & 12.8 & 9.0 & 10.8 \\
\hline Dismiss & 8.2 & 8.3 & 9.3 & 9.6 & 11.5 & 11.0 & 14.0 & 12.1 & 13.4 & 13.5 & 14.1 & 14.3 & 12.0 & 11.6 \\
\hline Other & 29.1 & 29.9 & 27.1 & 28.9 & 24.2 & 25.4 & 28.7 & 27.9 & 29.4 & 34.9 & 37.3 & 31.3 & 42.4 & 30.7 \\
\hline \hline Total & 74,558 & 77,141 & 75,434 & 76,949 & 78,154 & 68,858 & 67,047 & 87,481 & 80,261 & 77,934 & 81,245 & 78,229 & 89,120 & \\
\hline
\end{tabular}

Table 12: Civil Litigation Outcomes in Civil Cases Handled by U.S. Attorneys in District Court, 2001-2013

In order to address the unknown nature of the "other" categorization, we excluded "other" outcomes and recalculated the government's success rate. When we excluded "other" outcomes from the analysis, we find that the federal government prevails in civil cases handled by the U.S. Attorney's Office $59.7 \%$ of the time, settles $24.8 \%$ of these cases, and loses $15.5 \%$ of the cases. ${ }^{211}$ By comparison, the federal government won $63.3 \%$ of its NEPA cases from 2001 through 2013, had neutral outcomes in $18.1 \%$ of these cases, and lost $18.6 \%$ of its NEPA cases. ${ }^{212}$

When focusing on general environmental and land use litigation in which it is a defendant, the federal government also wins less and loses less and settles less than it does in NEPA-specific litigation. The federal government won just $41.6 \%$ of all environmental and lands litigation in which it was involved between 2001 and $2013 .{ }^{213}$ However, it also only lost $6.4 \%$ of such cases. ${ }^{214}$ The federal government settled $11.2 \%$ of its environmental and lands cases during that same time period, leaving a significant portion of such cases (40.8\%) with an unknown "other" class of outcome, as shown in Table 13.

When we exclude "other" outcomes we find that the federal government prevails in $70.3 \%$ of environmental and lands cases in which it is a defendant, settles $18.9 \%$ of those cases, and loses $10.8 \%$ of the time. As noted above, the federal government won $63.3 \%$ of its NEPA cases from 2001 through 2013, had neutral outcomes in $18.1 \%$ of these cases, and lost $18.6 \%$ of its NEPA cases.

211 Annual Statistical Reports, supra note 76.

212 See supra Table 11.

213 Annual Statistical Reports, supra note 76.

214 Id. 


\begin{tabular}{|c|c|c|c|c|c|c|c|c|c|c|c|c|c|c|}
\hline & 2001 & 2002 & 2003 & 2004 & 2005 & 2006 & 2007 & 2008 & 2009 & 2010 & 2011 & 2012 & 2013 & Avg. \\
\hline For U.S. & 22.4 & 21.5 & 30.0 & 34.9 & 31.3 & 31.3 & 29.4 & 28.7 & 24.4 & 22.2 & 25.4 & 25.2 & 25.3 & 27.0 \\
\hline Settled & 13.3 & 10.5 & 10.0 & 12.2 & 12.2 & 10.7 & 9.5 & 12.6 & 11.8 & 15.3 & 9.5 & 8.0 & 7.8 & 11.2 \\
\hline $\begin{array}{c}\text { Against } \\
\text { U.S. }\end{array}$ & 7.0 & 5.3 & 7.9 & 5.9 & 8.2 & 7.7 & 7.0 & 5.4 & 3.9 & 5.8 & 5.2 & 5.4 & 8.0 & 6.4 \\
\hline Dismiss & 17.0 & 15.6 & 16.1 & 14.6 & 12.0 & 10.0 & 17.4 & 13.0 & 17.2 & 13.8 & 13.2 & 13.1 & 14.5 & 14.6 \\
\hline Other & 40.3 & 47.1 & 36.1 & 32.5 & 36.3 & 40.4 & 36.7 & 40.4 & 42.7 & 42.9 & 46.6 & 48.3 & 44.4 & 40.8 \\
\hline \hline Total & 670 & 646 & 621 & 542 & 534 & 431 & 472 & 485 & 459 & 464 & 401 & 389 & 387 & \\
\hline
\end{tabular}

Table 13: Civil Litigation Outcomes, Environmental/Lands Matters, U.S. as a Defendant, 2001-2013 ${ }^{215}$

Regardless of whether we include the "other" category in calculating the federal government's overall win rates in civil litigation and environmental-specific litigation, these rates differ slightly from NEPA-specific litigation outcomes using the CEQ's data. While our results differ somewhat from the findings contained in a recent study from Professors Adelman and Glicksman, we do find that the federal government prevails in the majority of cases. In their study, Adelman and Glicksman examined NEPA litigation using a database created specifically for that project. That study observed that plaintiffs prevail in NEPA litigation at rates similar to those in other challenges to federal agency actions. ${ }^{216}$ That study also noted that the federal government wins around $70 \%$ of challenges to agency actions. ${ }^{217}$

Adelman and Glicksman's study observed that environmental plaintiffs won substantially more often than other plaintiffs in NEPA litigation at both the district court and on appeal. ${ }^{218}$ This appears to indicate that environmental plaintiffs are more selective than their peers in deciding whether to engage in NEPA litigation, which contradicts arguments that environmental plaintiffs are making frivolous claims in order to unnecessarily delay federal projects.

215 Id.

216 Adelman \& Glicksman, supra note 12, at 27-28.

217 See id. at 27-28 n.111 (looking at the success rates for challenges to agency action from various empirical studies, citing Thomas J. Miles \& Cass R. Sunstein, The Real World of Arbitrariness Review, 75 U. CHI. L. REV. 761, 767-68 (2008) ("reporting data on administrative review cases involving EPA indicating that agencies prevailed on average $72 \%$ of administrative challenges on appeal"); Richard J. Pierce \& Joshua Weiss, An Empirical Study of Judicial Review of Agency Interpretations of Agency Rules, 63 ADMIN. L. REV. 515, 515 (2011) ("observing that '[c]ourts at all levels of the federal judiciary uphold agency actions in about $70 \%$ of cases' irrespective of the standard of review that they apply"); Richard J. Pierce, What Do the Studies of Judicial Review of Agency Actions Mean?, 63 ADMIN. L. REV. 77, 84-85 (2011) ("synthesizing the results of numerous empirical studies of judicial review and finding that agencies prevail in $64 \%$ to $81 \%$ of the cases at the circuit level")).

218 Id. at 27 (noting that environmental plaintiffs win 35\% of NEPA cases at the district court and $27 \%$ on appeal, while other plaintiffs win just $16 \%$ of NEPA cases at the district court and only $14 \%$ on appeal). 


\section{CONCLUSION AND RECOMMENDATIONS}

The vast majority of federal actions that are subject to NEPA review are evaluated through an expedited analysis contained in either a CE $(95 \%)^{219}$ or an EA (5\%). ${ }^{220}$ Less than $1 \%$ of federal actions require an EIS. ${ }^{221}$ Overall, just $0.22 \%$ of NEPA actions-or 1 in 450 -result in litigation, and NEPA litigation represents just $0.043 \%$ of all civil environmental litigation in which the federal government is a defendant. ${ }^{222}$ The rate at which NEPA decisions are challenged in court is also generally in decline. The volume of NEPA litigation simply does not appear unduly burdensome, especially given the important dual goals of reducing environmental impacts and fostering public involvement in federal decisions impacting the environment.

While EISs are more likely to result in litigation than either EAs or CEs, this should not come as a surprise because EISs are reserved for the most complex, contentious, and impactive $1 \%$ of federal projects. Even so, both the number of EISs completed annually and the volume of NEPA litigation are declining while federal agencies are prevailing in litigation at an increasing rate. Environmental plaintiffs appear to be quite selective in the cases that they bring, given both the small number of suits brought annually and their record of prevailing at a higher rate than non-environmental plaintiffs. This finding contradicts claims that environmental organizations are abusing the courts by the frequent filing of frivolous claims.

NEPA litigation, in short, does not appear unduly burdensome. This is not to say that there is no room for NEPA reform, but rather, that efforts to reduce litigation or expedite production of NEPA documents are likely to have limited benefit while potentially undermining important national goals. Streamlining NEPA also runs a risk of actually delaying project implementation if, as our analysis suggests, the rate of challenge is inversely related to the time spent on the NEPA analysis. We therefore encourage Congress, the CEQ, and other agencies that are contemplating revisions to NEPA's implementing regulations to look beyond impassioned rhetoric and ensure that any reform efforts are based on sound data.

Having taken a hard look at NEPA litigation, our conclusions and recommendations are twofold: First, our analysis of the CEQ's NEPA completion time data, NEPA litigation data, and U.S. Attorneys' Office data on all federal civil litigation demonstrates that the attacks against NEPA and NEPA litigation focus on a nonexistent problem. Second, we nonetheless recognize that there is still room for improvement and suggest that any improvements made should be based on hard data, not

219 U.S. Gov'T ACCOUNTABILITY OFFICE, supra note 9, at 8.

220 Id.

221 Id.

222 See supra Table 4 (comparing the number of NEPA lawsuits filed to the total number of civil lawsuits against the federal government). 
anecdotes. In order to make better data-driven decisions, agencies need complete and accurate data. As previously noted, the EPA provides a complete record of published EISs, but there is not a similar repository of statistics on other types of NEPA documents (EAs and CEs), and "data collection efforts vary by agency." 223 The inconsistency in recordkeeping among agencies, and the lack of a centralized repository of NEPA documents, or even a record of the number of NEPA actions by agency, is problematic because an estimated 99\% of all NEPA reviews occur via CEs and EAs. ${ }^{224}$ Therefore, any NEPA reform should begin with an effort to increase and standardize NEPA document data collection and publication across all agencies. We found the BLM's ePlanning website ${ }^{225}$ to be easy to use and believe that it could provide a model for other agencies. In addition, we recommend that the CEQ reinitiate its lapsed data collecting efforts on NEPA litigation and designate a staff person to maintain these records and standardize the labelling of litigation outcomes, document types, and agencies.

We also recommend amending agency guidelines and rules that impose strict deadlines and page limits on EISs, as expedited NEPA analysis appears more likely to result in litigation. While we lack the data needed to test whether fast-tracked NEPA projects fare less well when challenged, we suspect that to be the case because regardless of streamlining efforts, the test of NEPA adequacy remains whether the agency took a hard look at the issues. Satisfying the same standard under artificial time or page constraints is, in our opinion, likely to prove problematic.

223 U.S. GOV'T ACCOUNTABILITY OFFICE, supra note 9 , at 7.

$224 \mathrm{Id}$. at 8.

225 ePlanning Project Search, supra note 75. 